\title{
'Purest Bones, Sweet Remains, and Most Sacred Relics.' Re-Fashioning St. Kazimierz Jagiellończyk (1458-84) as a Medieval Saint between Counter-Reformation Italy and Poland-Lithuania
}

\author{
Ruth Sargent Noyes (D)
}

check for updates

Citation: Noyes, Ruth Sargent. 2021. 'Purest Bones, Sweet Remains, and Most Sacred Relics.' Re-Fashioning St. Kazimierz Jagiellończyk (1458-84) as a Medieval Saint between Counter-Reformation Italy and Poland-Lithuania. Religions 12: 1011. https://doi.org/10.3390/rel12111011

Academic Editor: Nils

Holger Petersen

Received: 6 October 2021

Accepted: 10 November 2021

Published: 16 November 2021

Publisher's Note: MDPI stays neutral with regard to jurisdictional claims in published maps and institutional affiliations.

Copyright: (C) 2021 by the author. Licensee MDPI, Basel, Switzerland. This article is an open access article distributed under the terms and conditions of the Creative Commons Attribution (CC BY) license (https:// creativecommons.org/licenses/by/ $4.0 /)$.
Middle Ages, Renaissance and Numismatics, National Museum of Denmark, Frederiksholms Kanal 12, 1220 Copenhagen, Denmark; rno@natmus.dk

\begin{abstract}
This article explores the Counter-Reformation medievalization of Polish-Lithuanian St. Kazimierz Jagiellończyk (1458-1484)—whose canonization was only finalized in the seventeenth centuryas a case study, taking up questions of the reception of cults of medieval saints in post-medieval societies, or in this case, the retroactive refashioning into a venerable medieval saint. The article investigates these questions across a transcultural Italo-Baltic context through the activities of principal agents of the saint's re-fashioning as a venerable saint during the late seventeenth century: the Pacowie from the Grand Duchy of Lithuania and the Medici from the Grand Duchy of Tuscany, during a watershed period of Tuscan-Lithuanian bidirectional interest. During this period, the two dynasties were entangled not only by means of the shared division of Jagiellończyk's bodily remains through translatio - the ritual relocation of relics of saints and holy persons-but also self-representational strategies that furthered their religio-political agendas and retroactively constructed their houses' venerable medieval roots back through antiquity. Drawing on distinct genres of textual, visual, and material sources, the article analyzes the Tuscan-Lithuanian refashioning of Kazimierz against a series of precious reliquaries made to translate holy remains between Vilnius to Florence to offer a contribution to the entangled histories of sanctity, art and material culture, and conceptual geography within the transtemporal and transcultural neocolonial context interconnecting the Middle Ages, Age of Reformations, and the Counter-Reformation between Italy and Baltic Europe.
\end{abstract}

Keywords: relics; reliquary; Lithuania; Vilnius; Italy; Florence; Baltic; Counter-Reformation; Medici

\section{Introduction: Purest Bones, Sweet Remains, and Most Sacred Relics}

Rejoice, noble and splendid Italy, from which arose both Litalinian [sic] and Lithuanian high nobility, from which was also born Casimirus, whose primeval origin was there. ${ }^{1}$ Rejoice vast and spacious Sarmatia for conquering frost, cold and your own barrenness, to produce this most beautiful and blissful tree of life, yielding the sweetest fruit of virtue and honor. Rejoice holy and pious Mother Church, for bringing into the light Casimir as a true son of Christ and a warrior for the faith. Rejoice Poland for its most religious kings and Lithuania for its most magnificent dukes. Above all, rejoice Vilnius-the glorious city, where Casimir's purest bones, sweet remains, and most sacred relics will be kept for posterity as a guarantee of his immortality and glory (Ferreri 1521a, n.p.). ${ }^{2}$

In 1521, Bishop of Gardialfiera Zaccaria Ferreri (1479-1524), dispatched by Pope Leo X (Giovanni di Lorenzo de' Medici, 1475-1521) as papal nuncio to Poland-Lithuania, penned this litany in Vita Beati Casimiri (Life of the Blessed Casimir). ${ }^{3}$ Ferreri's hagiography of Polish-Lithuanian Prince Kazimierz Jagiellończyk (1458-1484) initiated from north-eastern Europe a propaganda campaign for the canonization of the pious prince in the papal city. ${ }^{4}$ Kazimierz was descended from the venerable Jagiellons, a Medieval lineage founded by 
the pagan-born Grand Duke of Lithuania Jogaila (Władysław II Jagiełło, c. 1362-1434) who had first forged the Polish-Lithuanian Union of Krewo (or Act of Krèva) in conjunction with his marriage to Queen Jadwiga of Poland and conversion to the Roman faith (Frost 2015). Destined to rule over Poland-Lithuania after his father King Kazimierz IV Andrzej Jagiellończyk (1427-1492), Prince Kazimierz renounced the crown to pursue a (albeit brief) life of holiness.

The intervening years between Kazimierz's death and the inception of his cult at the cusp of the late Middle Ages and the Reformations of the sixteenth century on the one hand, and his official elevation to the honor of the altar at the inception of the CounterReformation of the seventeenth century on the other, witnessed an inflection point for his homeland. In 1569 at the Union of Lublin, Polish and Lithuanian magnates (the wealthiest and most powerful members of the szlachta, or nobility) agreed to bind together their respective composite polities "in perpetuity," forming a confederated political entity that replaced a looser medieval union of 1385 (Frost 2015). Vita Beati Casimiri was published in Krakow, together with Vilnius the two capital cities of the historical territory of the PolishLithuanian Commonwealth (also known in the early modern period as Rzeczpospolita), a dualistic state consisting of the Grand Duchy of Lithuania and the Kingdom of Poland ruled by a common elected monarch, and one of Europe's largest nations comprising areas of present-day Lithuania, Poland, Latvia, Belarus, and Ukraine. ${ }^{5}$

Although the prince's life coincided with the conclusion of his kingdom's long Middle Ages and his cult first blossomed under one Florentine pontiff at the onset of the era of Reformations of the sixteenth century, his legal canonization was only incrementally finalized in the context of curial canonization reforms following Trent through a series of piecemeal Vatican documents over the course of the seventeenth century $(1602,1604,1621$, 1636), as the Catholic Counter-Reformation reached its full momentum under another Florentine, Pope Clement VIII (Breve apostolicum 1602; Officium S. Casimiri 1603; Theatrum S. Casimiri 1604; Žygas 1996). By the turn of the seventeenth century, he ranked among the so-called Beati moderni (modern Blesseds), would-be saints popularly celebrated but not legally sanctioned by the Vatican who constituted a crucial aspect of the actual diversity of figures serving as objects of devotion in post-Tridentine Catholicism (Ditchfield 2007, 2009; Noyes 2018).

Amongst the Beati moderni Jagiellończyk represented an exceptional case, insofar as Ferreri's Vita, both the precondition and product of legal inquiries led by the bishop towards official sanctification in Rome, coincidentally marked the inception of an unofficial hiatus in canonizations by the Roman Curia. This interruption, brought on by Protestant assaults on the cult of saints and uncertainties amongst authorities of the Catholic Church, would last from 1523 to 1588 (Ditchfield 1995). These circumstances positioned Kazimierz as an especially interstitial holy figure at the intersection of historical, geo-cultural, and religio-political régimes. Despite Kazimierz's canonization only being realized during the first half of the seventeenth century, the Counter-Reformation revisionistically celebrated him as having been awarded sainthood by Leo X already in 1521 (Maslauskaite 2005). The authoritative Martyrologium Romanum (Roman Martyrology) precociously included him from the 1580s (Baronio 1586).

This article explores how and to what ends transregional hagiography of the CounterReformation interconnecting the Italian and Lithuanian spheres undertook a discursive medievalization of Jagiellończyk to re-fashion the pious prince as a venerable saint by means of constructing for him a medieval pedigree and selfhood. The articles' first section investigates these questions through the activities of principal agents of the saint's refashioning during the later seventeenth century, including the leading families of the Pacowie (or Pac) from the Grand Duchy of Lithuania and the Medici from the Grand Duchy of Tuscany, during a watershed period of Tuscan-Lithuanian bidirectional interest. Section 2 demonstrates that during this period, the Medici and Pacowie were entangled not only by means of the shared division of the prince's bodily remains through translatioritual relocation of relics of saints and holy persons—but also mutual self-representational 
strategies. ${ }^{6}$ The third section reframes the Italo-Lithuanian refashioning of Kazimierz against an in-depth analysis of the material and technical fabrication of a series of precious reliquary containers to translate holy remains on behalf of the Pacowie and Medici between Vilnius and Florence.

This microhistorical case study takes up the issue of questions of the reception-or in this case the retroactive construction-of cults of medieval saints in post-medieval societies to disclose the entangled histories of sanctity, art and material culture, and conceptual geography within the transtemporal and transcultural neocolonial context interconnecting the Middle Ages, Age of Reformations, and the Counter-Reformation between Italy and Baltic Europe. Cumulatively, what follows argues that Italian and Baltic engagement more broadly, and Medici-Pacowie involvement specifically, with the manifold discursive, material, and performative manipulations of Jagiellończyk's cult and relics, served to further religio-political agendas, reaffirm the transtemporal unity of the cult of saints and relics, and retroactively construct venerable medieval roots back through antiquity for the respective regions and dynasties. Moreover, it will be shown that these activities linking Tuscany and Lithuania through Kazimierz attempted to obfuscate the threats of precarity and discontinuity affecting the saint, dynasties, and states involved.

\title{
2. MALO MORI QUAM FOEDARI: The Making of St. Kazimierz between Italy and Lithuania
}

\author{
Casimir gives a bright dawn \\ to the desired joys \\ of both Italy and Sarmatia, \\ from whence he derives his origin [ ... ] \\ Better to die than transgress \\ the boundaries of chastity [ ... ] \\ Defend your people \\ against the frenzy of war, \\ against the Scythians and impious \\ sects and other schisms. ${ }^{7}$
}

This passage from Ferreri's Vita Beati Casimiri, alternately exulting and then directly exhorting Prince Kazimierz Jagiellończyk, evinces a complex interwoven rhetoric inflected by notions of saintly moral purity, space and cultural geography, and pious religious reform and crusade. The text presciently captured key aspects of the Jagiellonian cult that would be promoted within and between Italian and Lithuanian realms more than a century later. The ancient Scythians were nomads in Eurasian territories, including present-day Ukraine and areas of Russia and Siberia, first noted by Greek historian Herodotus (490/480-425 BCE) in History of the Persian Wars (Rubinson 1975). Through the early modern period and with slight regard for actual historical geography, authors such as Ferreri continued to use the term Scythian to refer to non-Christian or other heretical groups in north-eastern Europe (Harmatta 1996). For the nuncio, it could refer to diverse heretics and schismatics in the Baltic, including (among others) Tatars, Turks, Orthodox (Russian) peoples, as well as early Protestants, while it also reinforced the region's classical inheritance.

Ferreri himself promoted early Catholic reform efforts in the territories of the Rzeczpospolita prior to the Council of Trent: he participated in the burning of Lutheran texts (Ferreri 1992, pp. 118-19), has been credited with helping to bring about Jagiellonian King Zygmunt I's 1520 ban on distribution of Lutheran texts (Ferreri 1521b; Kriegseisen et al. 2016, p. 341), issued his own 1521 anti-Lutheran ban from Vilnius, which also exhorted the general moral reform of Lithuanian clergy (Kriegseisen et al. 2016, p. 342; Ferreri 1992, pp. 86-93), delivered and published a 1521 oration before the Polish monarch condemning Lutheranism and praising the Commonwealth's Catholic orthodoxy (Ferreri 1521b, 1992, pp. 108-16; Nowakowska 2014, pp. 48-49), addressed a letter to Polish-Lithuanian clergy condemning Luther as a heretic (Ferreri 1992, pp. 124-25), dispatched from Poland a letter exhorting Martin Luther to return to Catholicism (Ibid., pp. 119-23), and oversaw 
publication of Pope Leo X's anti-Lutheran 1520 bull Exsurge Domine (Kriegseisen et al. 2016, p. 353$){ }^{8}$

The text of Ferreri's 1521 Oratio was issued from the same Cracow printing house that produced Vita Beati Casimiri. Both works included a woodcut author portrait depicting Ferreri as divinely inspired author in the tradition of representations of Church Fathers and Apostles accompanied by the inscription, "Faciem tuam illumina super servum tuum domine et doce me justifications tuas" (Psalm 118 (119): Let your face shine upon your servant, O Lord, and teach me your statutes). ${ }^{9}$

In Ferreri's Jagiellonian hagiography, the nuncio's likeness was paired as in a diptych with a woodcut title page portrait of the saintly prince. (Figures 1 and 2). Kazimierz's long fur-collared mantle and crown echoed the bishop's clerical tabarro (long mantle) with short pellegrina cape and square biretta cap. The splendorous rays framing the saintly face reappear as the cleric's source of inspiration, streaming through the window to illuminate his work. ${ }^{10}$ This coupling linked reform efforts and anti-Lutheran polemic with promulgation of Jagiellończyk's cult as a so-called "white," spiritual, or bloodless martyr, and a warrior, both in internal spiritual struggles and violent physical battles against enemies of the Catholic faith. ${ }^{11}$ Starting with Ferreri, hagiography fashioned Jagiellończyk into a polysemous figure bodying forth complimentary notions of chastity and fertility intrinsically linked to his homeland. The passage cited above described him as a "beautiful and blissful tree of life" and "fruit of virtue and honor" whose advent heralded his native land's conquest over "frost, cold and ... barrenness." The above verses linked his dual birth from Lithuanian and Italian origins (on which more shortly) to protection and victory against heresies in the region. Similarly, his woodcut portrait endowed him with the crown and white lily symbolizing his status as spiritual martyr, set against a landscape marked by desolate rocks and thorny branches. From the bare vegetation spring gracefully curved bows that blossom into florid leaves, echoing both the lilies and the botanical pattern on his brocade mantle. The garment's fur lining reveals itself to have been pieced from ermine pelts, the animal's black-tipped tales dangling from the wide collar.

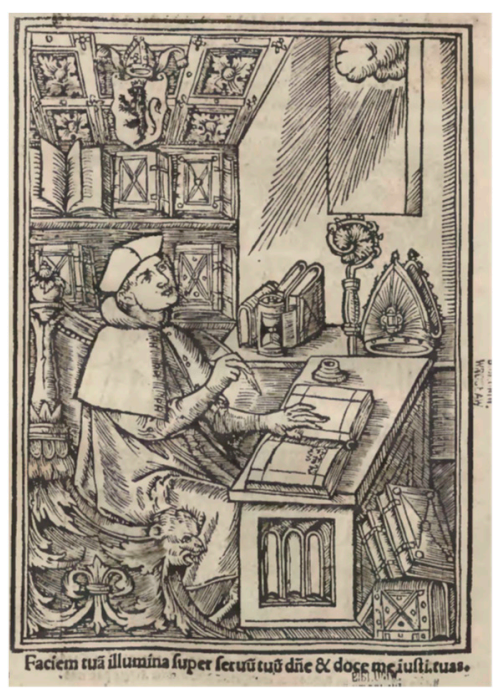

Figure 1. Portrait of Zaccaria Ferreri. In (Ferreri 1521a). Image in the public domain. 


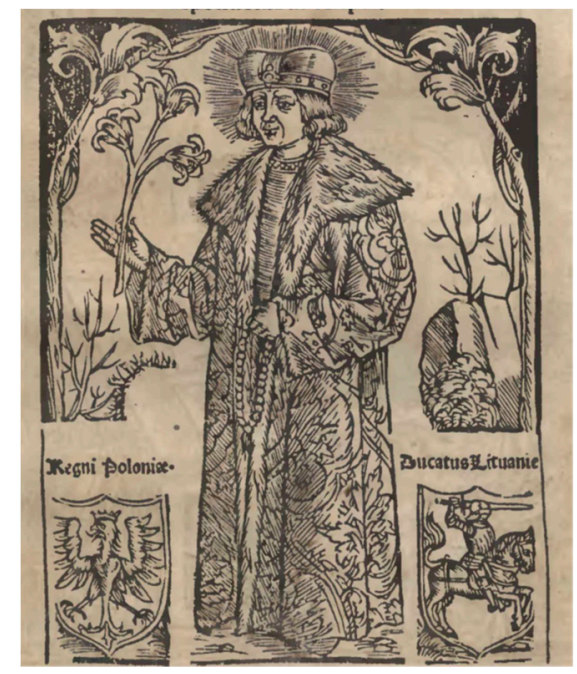

Figure 2. Portrait of Kazimierz Jagiellończyk. In (Ferreri 1521a). Image in the public domain.

By the Counter-Reformation, like many of his fellow Beati moderni Kazimierz was celebrated as a saint of white martyrdom, a species of non-violent martyrdom that was self-inflicted through strict chastity, self-abnegation, mortification of the flesh, and pious spiritual exercises (Noyes 2018, pp. 184-85). According to seventeenth-century hagiographies, "This most chaste prince [Kazimierz] could rightly be called a Martyr of Chastity, because he was such a studious observer of chastity that he elected to die an early death ..." (Ercole 1687, p. 8). The prince purportedly spent nights prostrate outside on the bare ground meditating on the Passion (di S. Antonio 1629, pp. 24-25), wore a spiked iron chain against his bare skin (Ibid., p. 23), and induced death-like ecstasies through intense spiritual devotion to objects and images (Ibid., p. 81). He also ignored doctors' warnings that sexual intercourse would improve his health, instead rejecting marriage and thereby ultimately bringing about his premature demise (Ibid., p. 59).

Ferreri coined the neologism Litalinian, eliding the toponyms Lituania (Lithuania) and Italia (Italy). He adapted this term to create an adjective delineating hybrid Italo-Lithuanian noble identity in the service of promoting the Jagiellonian cult and cause for canonization (Dini 2014, pp. 164-66). ${ }^{12}$ He went so far as to claim that the Grand Duchy should be called Litaliania rather than Lituania, as the name ultimately derived from l'Italia (Dini 2010, 2014). Though his terminology may have been novel, the concepts undergirding it were not: the Italianizing (even Romanizing) of the Lithuanian nobility's origins from fugitives and immigrants of the Roman empire who settled on the Baltic littoral was widely theorized from the fifteenth century amongst Italian and Lithuanian erudites. ${ }^{13}$ Ferreri's linkage was grounded on the account of Polish ecclesiast and historian Jan Długosz (Johannes Longinus; 1415-1480) who theorized on the basis on linguistic similarities between Latin and Lithuanian that "Lithuanians ... are descended from Latins, and if not from the Romans, at least from another people with the Latin name" (Dini 2014, p. 47). ${ }^{14}$ The nuncio leveraged Długosz's theory to claim that the Lithuanian nobility descended directly from Italians (Ibid., 49). More generally, however, Ferreri's efforts reflected a much broader phenomenon whereby leading families across Europe (including the Medici) with help from humanists and scholars fabricated ancestry tracing dynastic lines back to illustrious figures from ancient classical history and legend, among whom the most popular were protagonists of the Trojan War (Burman 1989; Schoonhoven 2010).

Długosz, in turn, without citing sources for his theories, was likely inspired by late medieval fourteenth-century historian Peter of Dusburg (or Duisburg), a member of the Teutonic Order. ${ }^{15}$ The advent of this papal-mandated medieval military order in the Baltic as crusaders with a directive from Rome to convert and conquer (among others) pagan Lithuanians (from the thirteenth century) coincided with the region's (re)emergence in the Western historical record, cultural consciousness, and conceptual geography (Blomkvist 
2005; Tamm et al. 2011; Christiansen 2016). ${ }^{16}$ Dusburg's Chronicon terrae Prussiae (Chronicle of the Prussian Land) described the Prussian pagan cult center of Romove, suggesting that the name Romove (Roma novae, new Rome) originated in ancient Rome and comparing the power of its high priest to that of the pope (Kulicka 1980; Chojnicka 2010). Długosz similarly invoked the trope of Lithuania (specifically, Vilnius) as a "New Rome." He narrated how under Julius Caesar, the Roman prince Vilia (who had sided with the defeated Pompey) escaped the civil wars and made his way north with 500 compatriots and their families to found the city of Romnove, later renamed Vilnius in his honor (Orzeł 2019, p. 172). ${ }^{17}$ This myth was echoed by Maciej Miechowita (1457-1523) in his Descriptio Sarmatiarum Asianae et Europianae (Description of Asian and European Sarmatia), a work re-published in Italian, which referred to Lithuania as Litialia and its people at Litali, and confirmed the derivation of Vilnius from Vilia (Miechowita 1521, lib. 2, cap. II \& 1561, p. 96). Sixteenth-century theorist Michalo (or Michalonis) Lituanus opined: "Nos Lituani ex Italico sanguine oriundi sumus" (We Lithuanians are descended from Italian blood) (Lituanos 1642, p. 246). ${ }^{18}$

That Długosz had not only traveled himself to the urbe multiple times but also served as tutor to the royal sons-including the future saint Kazimierz (Knoll 1982, p. 9)-underscores the transcultural Italian and Lithuanian imbrications embodied and sanctified in the prince. Długosz's biography also retraced the trajectory that linked the theory of Lithuanian magnates' origins to the geographical concept of Sarmatia, an idea central in Długosz's scholarly oeuvre that had its own classical pedigree (Kulicka 1980). Sarmatia and Sarmatian selfhood likewise proved crucial in Jagiellonian hagiography starting with Ferreri, who used Sarmatia interchangeably with Lithuania. This underlines how conceptual geography, and its attending identity formation were intrinsically linked to promotion of Kazimierz's cult, and specifically to the re-fashioning of the prince as a venerable saint purportedly less "modern" than in reality. The authoritative Geography by Claudius Ptolemy (c. 100-70 CE), which proved a strong influence on early modern geography and cartography, situated Scythia east and north of a region termed Sarmatia (Dilke 1984). Ferreri's text referred to the Commonwealth as Sarmatia aligned with histories of the ancient Sarmatians, whose conquest of the Scythians in what would become the territories of Poland-Lithuania. This figured as a prolepsis for Catholicism's subjection of heresies, schisms, and sects in the region. ${ }^{19}$ The transhistorical association was galvanized in the 1570 map of European Sarmatia by Polish physician Andrzej Pograbka (or Pograbius, d. 1602) prepared soon after the Union of Lublin. ${ }^{20}$

The trope of "New Rome" appeared across late medieval-early modern foundational accounts of Lithuania (Stryjkowski 1582, p. 75; Chojnicka 2010). It also featured in a parallel origins story tracing the most prominent lines of Lithuanian nobility back to Roman patrician Palemon, supposedly from the line of Claudius (Suchocki 1987, pp. 59-60), whose immigration north with a group of compatriots during the reign of Nero implied their pious Christianity. ${ }^{21}$ The Jageillons were held to have descended from amongst Palemon's comrades and fellow noble refugees (Orzeł 2019, p. 173). In his influential histories of the later sixteenth century such as Kronika polska, litewska, żmódzka y wszystkiej Rusi (Chronicle of Poland, Lithuania, Samogitia and all of Ruthenia), Polish polymath Maciej Stryjkowski (c. 1547-93) compared Palemon's journey north in search of divinely promised lands of plenty to those of classical epic, especially Aeneas's flight from Troy, which perpetuated the analogy between Italy/Rome and Lithuania (Stryjkowski 1582, pp. 72-75; Orzeł 2019, p. 175). The Palemon legend was widely promulgated (and perhaps invented) across Italian Renaissance humanist texts of the fourteenth-fifteenth centuries. ${ }^{22}$ By the seventeenth century the topos, which under the aegis of Catholic Counter-Reform served to galvanize the Commonwealth leading elites' ties to Rome while also elevating the status of the Lithuanian magnate class in rivalry with that of Poland proper, became ubiquitous across Italo-Lithuanian culture (Baniulytè 2012, p. 34; Orzeł 2019, p. 173). ${ }^{23}$

The Pacowie were no exception to these cultural tendencies: from the mid-seventeenth century their family genealogy recorded roots amongst the ancient Roman aristocracy, eventually claiming their origins in the region of Etruria (the lands between the Tiber and 
the Arno Rivers), purportedly based on archival documents found in Italy (Baniulyte 2012, pp. 34-36), thus coupling their mythology to the Palemon legend (Baniulyte 2005b). Etruria was not only also the supposed homeland of Palemon (Stryjkowski 1582, p. 73) but also, beginning from the late Middle Ages, the self-fashioned seat of the invented ancient origins of the Medici who styled their dominion in Latin as Magnus Ducatus Etruriae (Grand Duchy of Etruria) (Schoonhoven 2010). In 1673, Mikołaj Stefan Pac (1626-1684) won the nomination to the Vilnius episcopate, but the Vilnius cathedral chapter with custodianship of Jagiellończyk's chapel and remains opposed his candidacy and Pac struggled to gain papal ordination (granted only in 1682), to this end making multiple trips to Italy in the 1670s to negotiate with the pope and recruit allies (Rachuba 1979). Pac concurrently reformed stewardship of the Vilnius cathedral treasury's sacral furnishings and holy relics, where Kazimierz held pride of place, as an expression of his faith and close connection to the divine, to legitimate his ecclesiastical authority and claim to spiritual hegemony (Czyż 2018).

In seeking jurisdiction over the Sarmatian prince's miraculous body and alliances with Italian powers, the Pacowie attended to their own dynastic ambitions. From their perspective, mediating the transfer to one of Europe's storied houses of a relic of a purportedly venerable Litalinian saint descended from what they maintained were common Roman aristocratic roots offered a pious lens through which to inflectively legitimize their own translatio imperii. Parallel to their appropriation of the Palemon legend, the Pacowie also grounded a specific Litalinian pedigree in the homonymic relation between their family name and that of Florentine Carmelite saint Caterina de' Pazzi, known as Maria Maddalena (1566-1607, canonized 1669). Born into the storied Tuscan patrician family and famed Medici rivals, Maria Maddalena was like Kazimierz, a spiritual white martyr who suffered extreme self-imposed asceticism and mystical visionary episodes (Copeland 2016). The Grand Ducal family in Tuscany and the Pacowie in Lithuania actively promoted Pazzi's cult, and the Lithuanian magnates even claimed common ancestry among the Pazzi family. ${ }^{24}$ The Pacowie held that after the Pazzi's exile from Florence in the wake of a failed anti-Medici coup in 1478 (Martines 2004), some banished members settled in Lithuania after fleeing Tuscany via Constantinople, effectively recapitulating the geographic trajectories of Palemon and the ancient Sarmatians. ${ }^{25}$ This claim of connected lineages was reinforced by the onomastic coincidence of the family names Pac (pronounced "patts") and Pazzi (pronounced "pattsi"), and made more plausible by that fact that the Pazzi had financial dealings in the Commonwealth during the fourteenth century (Martines 2004, pp. 63-82). The origins of the Pacowie's Italianization can be traced to early seventeenth-century papal and Medicean court circles, where propaganda directly connected to the Medici and the Vatican under a series of Tuscan popes vaunted the Pacowie as the "Pazzi in Lithuania." This positioned the family and Lithuania as north-easternmost bastion of the Roman Church and even successor to antique Roman imperium, such that the Pazzi-Pacowie legend might be considered "a special outgrowth of papal diplomacy in this region" (Baniulyte 2012, p. 26). ${ }^{26}$ When Bishop Pac's father Stefan Pac traveled through Italy in 1624-1625, he received an audience with the Florentine Pope Urban VIII, where he was accepted as a relative of the Florentine Pazzi: "When I kissed him, the pope told me that he was glad of my origins as a member of the Florentine family Signori Pazzi ... and I did not contradict him." (Baniulytè 2012, p. 30).27

3. It Was the Polar Winds That Have Led Me to the Conquest of the Sacred Treasure: St. Kazimierz and His Relics between Vilnius and Florence

It was the Polar Winds that have led me to the conquest of the sacred Treasure that is the longed-for relic of the saintly King [sic] Casimiro, with which I already see myself rewarded, when I will row my vessel through the danger of a thousand difficult obstacles and abysses before arriving at its possession. My heart cannot find words to express the joy that flooded my soul upon opening the message from Vilnius [ ... ] from whence comes to me such a precious and inestimable 
gift [ ... ] I now remain in a state of most joyous righteous impatience, as I hope for the venerable Relic ... . ${ }^{28}$

Framed with rhetoric entangling period notions of Counter-Reformation religiosity, holy crusade, classical maritime epic, nautical conquest, and cultural geography, this passage expressed the exultation and anticipation of Tuscan Grand Duke Cosimo III de' Medici (1642-1723). Cosimo was the penultimate patriarch of a dynasty that had dominated peninsular politics for two and a half centuries, and since 1670, he was ruler of the historical territory of the Grand Duchy of Tuscany, a Habsburg imperial fief covering much of westcentral Italy. ${ }^{29}$ Cosimo composed this triumphant paean upon receiving a dispatch from Vilnius in 1677 with the news that after nearly five years of petitions and negotiations, a relic from Sarmatian Prince St. Kazimierz Jagiellończyk (rendered in Italian as Casimiro in the grand duke's letter) would finally be granted to him. However, this precious treasure would only finally arrive in Florence nearly two years later, at the turn of the new year 1678-1679..$^{30}$ The relic and its precious containers came largely thanks to the intercession of Mikołaj Stefan Pac, the newly appointed Bishop of Vilnius. The Pacowie (or Pac) dominated Lithuanian politics in the latter seventeenth century and their rise to preeminence in the Baltic ran parallel that of the Medici in Italy (Codello 1970; Baniulyte 2009). ${ }^{31}$ By the 1660s, the family had become the Polish-Lithuanian King's main political allies and held all important positions in Lithuanian government (Kotljarchuk 2006, pp. 271-72 and ff.; Frost 1993, pp. 80-90). Their ascendancy within the Rzeczpospolita was attended and fueled by concurrent rapprochement and alliances with the papal court in Rome and Italian courts such as Medicean Tuscany. ${ }^{32}$

The multivalent rhetoric of Cosimo's triumphant letter should be read against the fact that in the previous century, Nuncio Ferreri's mission in the north also entailed negotiating peace with the Teutonic Order who had a long crusader legacy in the Baltic (Kriegseisen et al. 2016, p. 341). ${ }^{33}$ The nuncio's diplomatic missive three centuries after the Order's arrival in the region, and the Medici-Pacowie rapprochement 150 years after Ferreri, should be viewed against Counter-Reformation Italian promotion of the Jagiellonian cult over the course of the seventeenth century. ${ }^{34}$ This imbrication of Catholic religiosity and political ambitions must, in turn, be contextualized within Lithuania's long and complex entanglement with Italian powers. Lithuania's inclusion in the annals of Western history was concurrent to a movement to colonize and conquer it for Catholicism (Murray 2001; Blomkvist 2005) and was, thereafter, largely perceived by the West through a colonial and neocolonial lens (Caccamo 2010; Donecker 2016).

All these points reflected not only the deep history of trade, dynastic, and religioimperial crusader ties between Italy and the Baltic beginning from the Middle Ages, but also early modern interest in Baltic politics from ruling families in Italy. At the time of Ferreri's nunciature, Milanese-born Bona Sforza (1494-1557) was Queen of Poland and Grand Duchess of Lithuania, seemingly realizing the notion of Litalinian aristocracy. ${ }^{35}$ These transcultural currents were revived during the early modern era (Tygielski 2015), and the period of Kazimierz's official canonization around the turn of the 1600s. During this period, the Medici promoted family members to become King of the Polish-Lithuanian Commonwealth, to this end positioning Tuscan secretaries and informants at the Commonwealth courts and courting allies amongst the elite szlachta (Baniulyte 2012). After the death of Mattias de' Medici (1613-1667) - among the most favored candidates for the throne-Cosimo himself intended to participate in the 1669 and 1673 Commonwealth elections, eventually renouncing in favor of his brother Francesco's (1660-1711) candidature (Panella 1917; Quirini-Popławska 1982, 1998). Likewise, noteworthy is the fact that Cosimo regarded Russia as the gateway to China, thus casting in a more expansive field his dealings in north-easternmost Europe and Eurasia, as Tuscany sought to compete with other European global empires (Musillo 2020). Cosimo's avid desire for a piece of Casimiro was first expressed in 1673 (when he also contemplated the Polish-Lithuanian crown). This was the same year of Pac's nomination to the Vilnius episcopate. His nomination, 
as noted above, was opposed by the same Vilnius Cathedral chapter with custodianship of Kazimierz's precious "purest bones," thus delaying Pac's ordination until 1682 (Czyż 2018). In this context, the question of jurisdiction over the saint's relics became a heated point of contention, delaying the fulfilment of the Medici's yearning for a relic for years, and transforming the holy remains into a strategically liminal transregional borderland. The saint's body could be leveraged from multiple viewpoints to manifold religio-political and ideological ends, instantiating a Litalinian liminal zone wherein intercultural selfhood might be negotiated.

In this zone could be found the intersection of Pacowie and Medici interests. By the time Cosimo set his sights on the Baltic, the holy Sarmatian prince hovered at the threshold between Italy's long-held desire to establish a transregional Litalinian empire on the one hand, and on the other, the complimentary "othering" of the Baltic region that served both interior and exterior political, sociopolitical and cultural agendas (Wolff 1994), and harkened back to the Middle Ages (Donecker 2010; Barraclough et al. 2016; Jørgensen and Langum 2018). Baltic lands that twelfth-century papal-mandated crusaders conquered and christened Livonia (covering much of present-day Estonia and Latvia) for Latin Christendom, followed by the addition of Lithuania (through the Jagiellonian Christian conversion), were directly subordinated more than three and a half centuries to the Holy See, and spiritually and symbolically (if not administratively) unified and sanctified under the Roman curial aegis (Houben and Toomaspoeg 2008). Notably, Medicean imperial ambitions elsewhere (for example India) were also negotiated through the commissioning and collecting of, and engagement with, material manifestations of local saints' cults, including St. Francis Xavier in Goa and St. Thomas the Apostle in Mylapore (Benay 2020; Freddolini 2020). Cosimo's religiosity—considered exceptional amongst contemporaries—led him to fashion himself as spiritual crusader, pilgrim, and pious collector of relics as sacred spolia in the battle against heresies (Gennaioli and Sframeli 2014, pp. 244-47; Guzmán 2018; Spinelli 2019).

That Cosimo commissioned from Florentine artist Carlo Dolci (1616-1686) a likeness of Kazimierz that hung in the grand duke's bed chamber suggests his special devotion to the saint (Gennaioli and Sframeli 2014, pp. 272-73; Maslauskaitè-Mažylienè 2018, pp. 80-83). ${ }^{36}$ (Figure 3). Rendered in an ecstatic pose with marble-white skin and a skeletal countenance evincing his purity and self-abnegation, the prince is attended by the spray of lilies signifying his bloodless martyrdom. He is shown in the act of composing a devotional hymn to the Virgin. While painted in a distinctly late Baroque style, Dolci's portrayal of the fur-lined mantle and jeweled crown was inflected by much older depictions of the saint that traced back to Ferreri's woodcut. From the Medicean perspective, the grand duke sought a relic of a prince fashioned in hagiography as a spiritual crusader from a kingdom he himself designed (if only briefly) to rule, who numbered amongst the last pre-Tridentine saints raised to the altar by a Medici pope. Moreover, the saint's name rendered in Italian as Casimiro was a near homophone to the favorite grand ducal name Cosimo. The name itself retraced the dynastic line three centuries, through his Great-Great Grandfather and first Tuscan Grand Duke Cosimo I de' Medici (1519-1574), back to the venerable Cosimo di Giovanni de' Medici (1389-1464), effectively the founder of the Medici dynasty. The rise to power of the "first Cosimo" (known as Cosimo il Vecchio) in late medieval Florence overlapped with the Sarmatian prince's pursuit of spiritual martyrdom. 


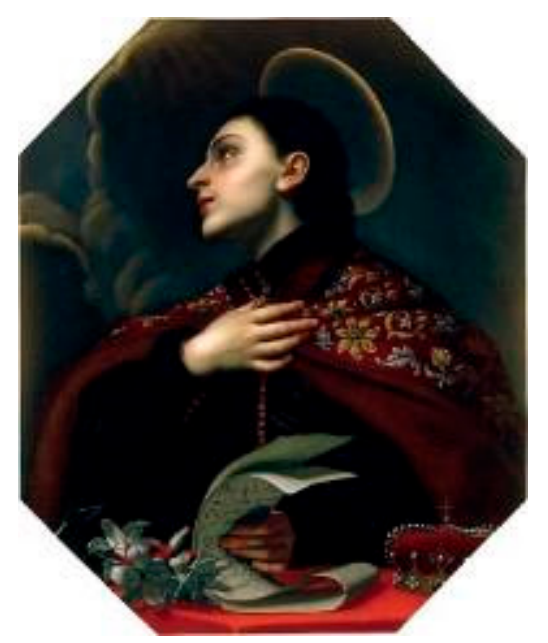

Figure 3. Carlo Dolci, Portrait of St. Kazimierz, 1670-1671. Pushkin State Museum of Fine Arts, Moscow. Image in the Public Domain.

During the seventeenth century, the last Medici grand duke graced with the name Cosimo pursued a relic of Casimiro. In addition to the above dynastic concerns, his quest was further sustained by a profound devotion to and ardent appetite for the rarest holy relics. His fervor was shared and indeed fostered by his Grandmother Maria Maddalena of Austria (1589-1631) and Mother Vittoria della Rovere (1622-1694). Renowned amongst contemporaries in their own right for their avid "relic diplomacy," these powerful women worked through the negotiation of gifts, exchanges, and acquisitions of saints' relics to ally and align their family with European powers and the divine (Sanger 2014, pp. 71-92; Modesti 2020, pp. 205-42). Following other avid relic seeking sovereigns such as King Philip II of Spain, the Medici patrons' deep religiosity and its material instantiation by means of collecting relics and their attending physical containers (reliquaries) not only consolidated and maintain diplomatic, social, affective, and spiritual relationships, but were also crucially constitutive of premodern paradigms of legitimate righteous rule, particularly in reformatory contexts (Lazure 2007). By the mid-1600s, the grand ducal family had amassed within the Cappella delle Reliquie (Chapel of Relics) in the Palazzo Pitti a breathtaking array of sacred remains distinguished for their size and rarity, together with a collection of reliquaries grouped according to material in special display cabinets for rock crystal, ebony, silver and amber (Gennaioli and Sframeli 2014, pp. 243-338). Within such a ritual setting charging them with a symbolic force heightened through their mobility, Tuscany's translated relics functioned on one level as intercultural mediators and agents of taste and transmitters of cultural capital, and on another level as galvanic transmitters of divine grace, much like metals conduct electricity (Hills 2016).

Cosimo's recourse in the above passage to the metaphor of a rowed galley ship propelled by oarsmen reflected the Tuscan galleys powered out of the Grand Duchy's port of Livorno. These ships were meant to conquer the Levant under the aegis of the Cavalieri di Santo Stefano (Order of St. Stephen), a Counter-Reformation pseudo-crusader order founded in 1561 by first Grand Duke of Tuscany Cosimo I de' Medici under papal mandate (Poole-Jones 2020; Silva 2020). The Order linked Tuscany and Rome and recalled crusader orders of the Middle Ages, fabricating a crusader heritage for the Medici who were otherwise lacking this aspect in their dynastic history (Brege 2020). Livorno also represented a direct Litalinian connection and interdependence between the livelihood of Tuscany and the bounty of the Baltic, as historically the Medici imported critical supplies of grain from primarily Poland-Lithuania through the port (Ghezzi 2012, pp. 105-18; Tazzara 2020a, 2020b, p. 71; Moore 2010a, 2010b). Despite the decline of Tuscan maritime power by the end of the century, in light of the historically critical role of Livorno enabling Tuscany's global imperial, crusader, and trade ambitions, Cosimo undertook reforms of the 
port, cultivating visions of Medicean supremacy predicated on Livorno's legacy (Tazzara 2020b).

The activities of the Livornese Cavalieri di Santo Stefano recast the Medici as CounterReformation crusaders in the medieval tradition in such a way that also projected their modern imperial ambitions against the Muslim threat in the Mediterranean. Similarly, Kazimierz Jagiellończyk's retrospective medievalization forged in reverse links in an unbroken chain that stretched back along the axis of human chronology, reaffirming the transhistorical unity of the cult of saints despite the ruptures of the Age of Reformations. This metaphorical chain also recalled that Lithuania-which remained pagan and resisted the Baltic crusades for centuries - in converting to Christianity concurrent to the founding of the Jagiellonian dynasty proved a propaganda coup for the Roman papacy and the Catholic faith (Rabikauskas 1989; Baronas and Rowell 2015). ${ }^{37}$ Notwithstanding the definitive disaggregation of the Baltic as a northern terra sancta during the reformations and wars of the sixteenth-seventeenth centuries, Counter-Reformation prerogatives ensured that this transregional imperium survived notionally as ideological relic sanctified in confessionalized historiography and reconquerable Holy Land in religio-political discourse. ${ }^{38}$ From the Middle Ages, conceptions from the perspective of Latin Christendom alternatively imagined north-easternmost Europe on the one hand as a barren barbaric wasteland and supernatural seat of devilish evil (Ström and Barbierato 2018; Donecker 2010; Barraclough et al. 2016). On the other hand, the region was also conceived in highly materialist terms as both Antemurale Christianitatis (Bulwark of Christendom) protecting Catholicism against manifold threats, and as Europe's "Indies" and vagina nationum (womb of nations). In this sense, it was viewed as a fertile "commodity frontier" naturally abundant in inviolate environmental resources (cereals and timber, fish and fauna, amber and silver), historically abundant in ancient peoples and nations, such as the Scythians and Sarmatians, and spiritually fecund with souls for conversion and conquest. ${ }^{39}$

These topoi were promulgated across epistemic spheres. This included hagiography cultivated in and in connection to the Italian milieu around the figures of the Baltic Beati moderni, who suffered both violent and non-violent martyrdom for heroic resistance against infidels, insurrection, and impiety in the north. These included in addition to Kazimierz, the Polish-Lithuanian Jesuit Stanisław Kostka (1550-1568; beatified 1605, canonized 1726) and Ruthenian Uniate archbishop Jozafat Kuncewicz (1580-1623; beatified 1643, canonized 1867). ${ }^{40}$ Jagiellończyk's hagiography vested him with the role of crusader-defender on behalf of Catholic forces in the Grand Duchy. One of the prince's earliest attributed posthumous miracles was his appearance intercession on behalf of the Lithuanian army against Muskovite forces, when Kazimierz appeared on a white horse at the Daugava River during the 1518 Siege of Polotsk (Ercole 1687, p. 9). Hagiography discursively assimilated the Baltic natural environment with these holy men's fertile capacity for converting souls and spiritual purity, concepts intertwined in Ferrerio's paean of Casimir addressed to "vast and spacious Sarmatia for conquering frost, cold and your own barrenness as you nurtured this most beautiful and blissful tree of life, yielding the sweetest fruit of virtue and honor." This tripartite environmental, corporeal, and spiritual elision of landscape, flesh, and soul materialized in their postmortem bodily incorruption, a miraculous manifestation suggesting the subject was divinely exempt from the physical process of decomposition. Historically recognized by the Church as an indicium sanctitatis and proof of resurrection, during the Counter-Reformation such posthumous corporal integrity became an unprecedented commonplace sign of sanctity, and increasingly verified by autopsy (Bouley 2017, pp. 70-90).

Following Kazimierz's provisional canonization in Poland-Lithuania, in 1604 Vilnius Bishop Benedykt Woyna presided over the ceremonial translatio of the saint's relics, entailing the elevation of his coffin from the Cathedral crypt and inspection of his corpse, which purportedly disclosed a remarkably preserved and sweet-smelling corpse even after 120 years. ${ }^{41}$ This beatific state seemingly realized the promise that the prince's "purest bones, sweet remains, and most sacred relics will be kept for posterity as a guarantee 
of his immortality and glory." In the 1620-1630s, at the initiative of Kings Sigismund III Vasa and Wladyslaw IV Vasa (the saint's great-nephew), a reliquary chapel to safeguard Kazimierz was erected adjacent to Vilnius cathedral under the oversight of Mikołaj Stefan Pac's father, Lithuanian Grand Treasurer and Deputy Chancellor Stefan Pac (1587-1640). The Jagiellonian reliquary chapel was designed and built by immigré Lombard (northern Italitan) architects Matteo Castelli (c. 1555-1632) and Constantine (Costante) Tencalla (1593-1646), who had worked on St. Peter's in Rome. ${ }^{42}$

Their design followed a domed central Greek-cross cruciform plan conceived as a pseudo-ancient martyrium, after Roman Counter-Reformation examples that revived the venerable genre used in the early centuries of Christianity and Middle Ages to enshrine martyrs' tombs. ${ }^{43}$ On 14 August 1636, King Władysław IV participated in the translatio of Jagiellończyk's relics in a silver casket (since lost) to the newly completed chapel (Chynczewska-Hennel 2006, pp. 191-96). The Vilnius chapel's lavish decoration, heavily damaged in subsequent decades, incorporated 500 square meters (1200 cubic feet) of marble, some imported from Italy (Jamski 2005a, pp. 506-9). This scheme not only articulated its devotional reliquary function, but also contextualized the saint's body beneath an altar mensa (since destroyed) of marble, ebony, and silver within a so-called confessio altar design behind a grilled opening (fenestella confessionis). This configuration had its origins in the papal city, and reproduced what was held to be a venerable Christian liturgical architectural arrangement for the conservation and ritual display of holy martyrs' relics (Wieland 1906; Jamski 2005b). ${ }^{44}$ Counter-Reformation historians maintained this was an ancient Christian liturgical architectural arrangement first initiated in the urbe, to mark the site where the first saints "confessed" and died for their faith (Ostrow 2009; Herz 1988).

During the Deluge (1648-1667), Muscovite forces occupied Vilnius, and as Casimir's "beloved body" was spirited away, the Russian army desecrated the city's many Catholic churches (Briedis 2008, pp. 55-56). Following the 1666 reconstruction on the Cathedral, Kazimierz's "purest bones" were translated back to the chapel, which underwent additional restorations 1691-1692 that included a fresco cycle painted by Tuscan-born Medici court artist Michelangelo (Michele Arcangelo) Palloni (1642-1712), who in 1676 or 1677 (around the same time that Jagiellończyk's relic was finally removed to be gifted to the Medici grand duke) migrated to Lithuania to work under the aegis of the Pacowie, almost certainly dispatched as a Medici protégé (Guidetti 2004, 2008). ${ }^{45}$ Palloni's mural program including a life-size scene depicting the miraculous incorruption of the saint's corpse in 1604, witnessed by a group of onlookers. (Figure 4). The group includes on the far right margin the figure of a well-attired magnate dressed and groomed according to a recognizably Sarmatist style adopted by the Polish-Lithuanian szlachta, which in the late seventeenth century would have been identifiably traditionalist, even old-fashioned (Grusiecki forthcoming). ${ }^{46}$ In contrast to the timeless ecclesiastical garb and eternally youthful intact body of the saint, this manifestly retardataire figure not only gestured to Kazimierz's august noble Sarmatian selfhood, but also fabricated an illusion of a Jagiellonian cultic tradition much older than actual fact. This interlocutor should be read against Palloni's depiction of Kazimierz, whose likeness-despite appearing intact and in the flower of youth-was actually copied from the old and comparatively crude woodcut portrait in Ferreri's 1521 Vita Casimiri and similarly medievalized the saint. 


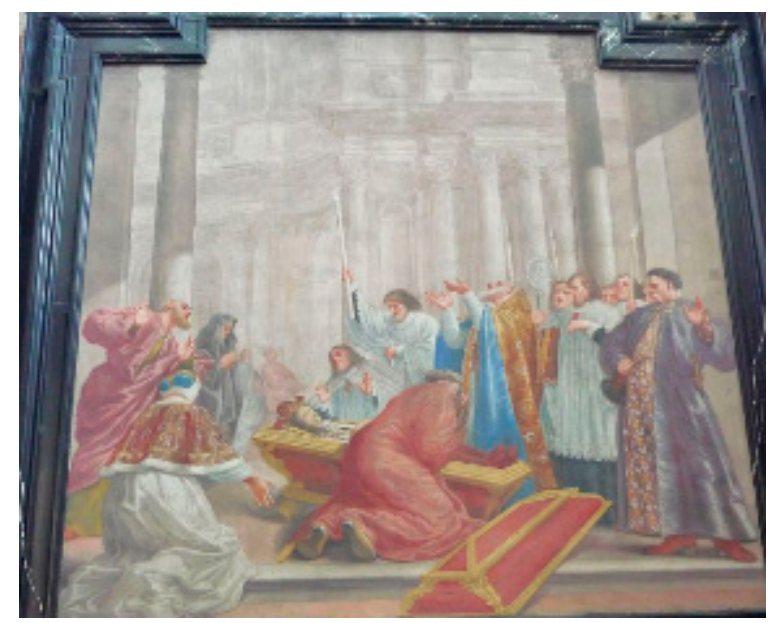

Figure 4. Michelangelo Palloni, Translatio and revelation of Kazimierz's miraculously preserved body, 1690s. Vilnius Cathedral, Lithuania. Photo by the author.

4. Whose Conquest Was Sought through the Pilgrimage of Both the Pen and the Mind: Translating St. Kazimierz Jagiellończyk and St. Maria Maddalena de' Pazzi

I cannot contain my immense pleasure from the joyful satisfaction of my great longings upon yesterday's arrival of the sacred Treasure, whose conquest was sought through the pilgrimage of both the pen and the mind, with the desire to reward myself. I speak of the inestimable relic of Glorious Prince St. Casimiro, which was accompanied by rich ornament: namely, a precious altar furnishing to safeguard the relic. These were handed over to me in this city [of Florence] by the Lord Abbot and by a gentleman of My Lord the Bishop of Vilnius, on behalf of him and the Vilnius Cathedral chapter. ${ }^{47}$

The relic of Kazimierz Jagiellończyk was at last delivered to Florence by envoys of Bishop Mikolaij Pac, Antonio Maria Principati and Aleksander (Alessandro) Buchuiz, before Christmas 1678. Grand Duke Cosimo III composed this victorious passage, celebrating his figurative "conquest" of the numinous Sarmatian treasure as the result of pious crusader pilgrimage undertaken virtually (through mental exertion) and by proxy (by means of epistolary exchange) to the Baltic in quest of the sacred trophy, a femur (or tibia) bone. ${ }^{48}$ The single largest relic of the prince known today was removed from the silver coffin safeguarding his remains on 27 October 1677 and furnished with a so-called Authentic certificate testifying to the details of the bone's ceremonial translatio and underscoring its exceptional extraction from "the relics of the intact body" of Kazimierz (Gennaioli and Sframeli 2014, pp. 270-71, 93-96; Maslauskaitė-Mažylienè 2018, pp. 57-58). ${ }^{49}$ Crafted from parchment, ornamented with golden illumination, and furnished with massive wax seals, the monumental Authentic was addressed from "Nicolaus Stephanus de Pazzis" to "Cosmo Magno Duci Hetruriae." The document was manufactured in the guise of a medieval diplomatic charter that instantiated the entangled myth-making surrounding the venerable origins of the dynasties involved and also backdated, as it were, the saint it both verified and metonymized (Maslauskaitè-Mažylienè 2018).

In imitation of the saint's martyrial entombment in Vilnius, his relic was placed in a silk-lined cypress casket within a silver coffin. Then, over the course of the next year, a third reliquary chest was manufactured in the Prussian coastal port city of Danzig (current-day Gdańsk, Poland), from ivory, wood inlay, and amber "with the richest ornaments and the likeness of the Holy Prince". ${ }^{50}$ (Figure 5). In October 1678, the precious treasure journeyed south accompanied by an amber crucifix and ensemble of amber altar furnishings, which Cosimo also celebrated for their exquisite luxury. In June 1679, six months after receiving the Kazimierz relic, the grand duke personally welcomed bishop Pac, en route to Rome to negotiate his papal confirmation. Pac stopped in Florence to deliver more luxury gifts to the Medici court from his cousin, Lithuanian Grand Hetman (i.e., commander of the 
armed forces) Michał Kazimierz Pac (1624-1682), to pay homage to the relics of another distant "cousin," St. Maria Maddalena de' Pazzi, and likely negotiate the reciprocal gift of the Florentine saint's relics. ${ }^{51}$ After the death of Bishop Pac and his other Pacowie contacts, in 1687-1688 Cosimo transferred the bone of Kazimierz from its amber casket to a new silver and gold reliquary made in Florence by leading artists of the Medici court.

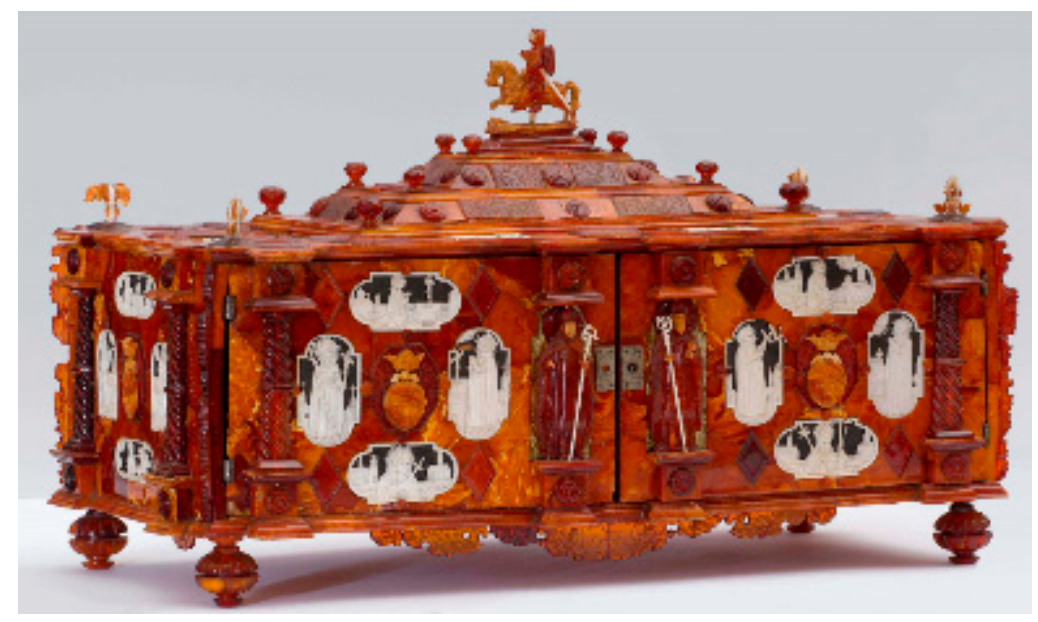

Figure 5. Danzig workshop, Reliquary of St. Kazimierz Jagiellończyk, c. 1677-78. Palazzo Pitti (Tesoro dei Granduchi), Florence. Image in the public domain.

What remains of this article maps the discursive materiality of a pair of sumptuous reliquaries to transport, safeguard, ostent, and exegetically frame the saint's relics, resonating concepts already intertwined in Ferreri's paean to "vast and spacious Sarmatia for conquering frost, cold and your own barrenness as you nurtured this most beautiful and blissful tree of life, yielding the sweetest fruit of virtue and honor." Despite their apparent differences, it will be argued against the backdrop of bidirectional Tuscan-Lithuanian self-fashioning and period entanglements of conceptual geography, historiography, and hagiography that these reliquaries in fact represented complementary elements within a mutually transformative system, essential to the medievalizing and archaizing of the saint, and "intelligible only through the relationships that unite them" (Lévi-Strauss 1982, p. 93).

At an impressive $35.5 \mathrm{~cm}$ wide, $58 \mathrm{~cm}$ long, and $20 \mathrm{~cm}$ high, the Danzig casket in which Kazimierz's bone was transported from the Baltic to the Tuscan littoral reveals itself to be a culturally synchronic heterotopic, heterotemporal site of interaction and entanglement amongst multitudinous bodies. In this object, Litalinian identities, nonhuman and human entities, divine and earthly ontologies, modern and medieval temporalities, and represented and material bodies cohabited and mingled. ${ }^{52}$ The Cappella delle Reliquie by the end of the seventeenth century housed over thirty amber items (Hinrichs 2007, pp. 266-69). ${ }^{53}$ Today, it stands out amongst the Medici's encyclopedic gathering of amber objects as the largest such chest. (Figure 6). It also stands out in terms of its style in contrast to other amber items owned by the Medici identified as having been made in Danzig during the same time period, which were fashioned according to a patently modern and Baroque aesthetic marked by graceful carved contrapposto figures, naturalistic forms, and sinuous, serpentine lines (see e.g., Gennaioli and Sframeli 2014, pp. 184-91). However, the Kazimierz reliquary presents as if it were a markedly older thing made during the Middle Ages. It evinces a distinctly antiquated stylistic vocabulary, characterized by rigidly frontal figures, schematized and abstracted block-like forms, and an overall stiffly monumental presence. (Figure 7). 

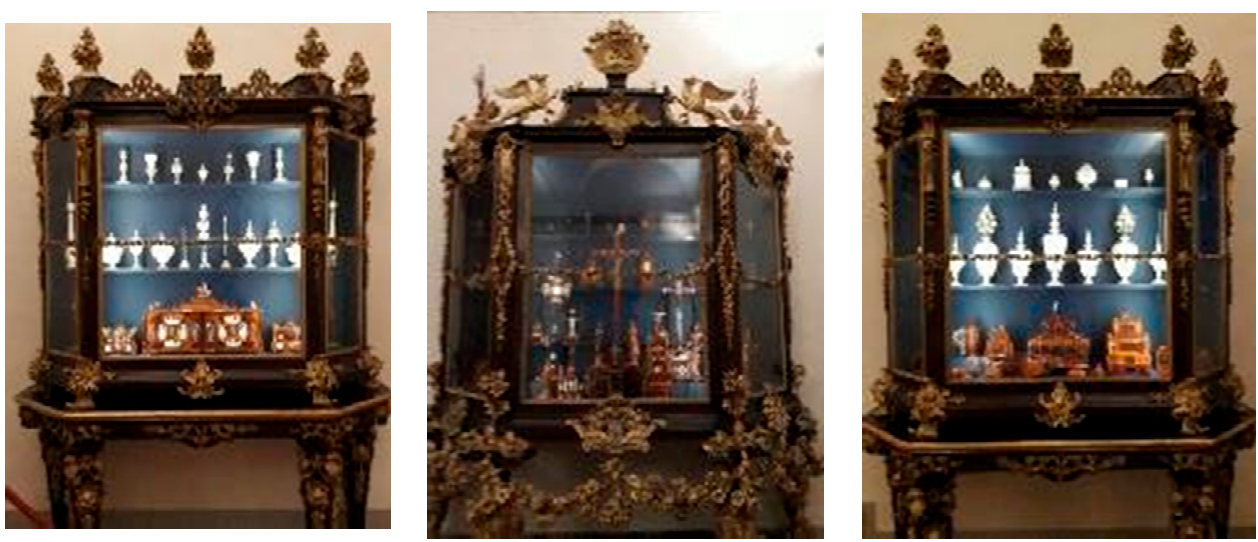

Figure 6. View of cabinets containing amber and ivory objects from the Medici collections with Kazimierz reliquary on far left bottom shelf. Palazzo Pitti (Tesoro dei Granduchi), Florence. Photos by the author.

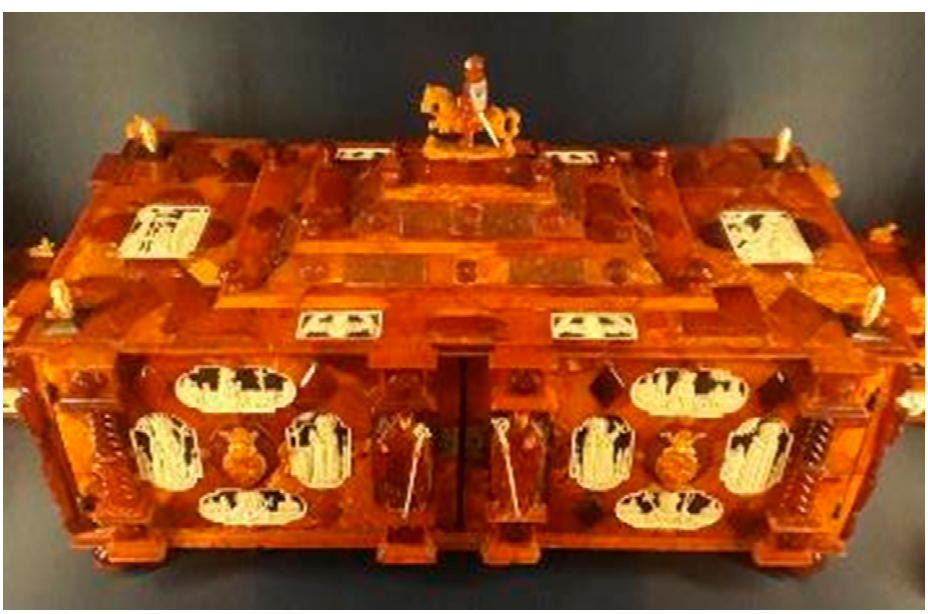

Figure 7. Danzig workshop, Reliquary of St. Kazimierz Jagiellończyk, c. 1677-1678. Palazzo Pitti (Tesoro dei Granduchi), Florence. Photo by the author.

Its construction consisted of a wooden frame overlaid with complex inlay composed of thin intricately carved plaquettes of various shades of amber, ebony, and ivory pieced together as a three-dimensional mosaic (Gennaioli and Sframeli 2014, pp. 266-67; Maslauskaitė-Mažylienè 2018, pp. 74-76). The architectonic form gestured both to reliquaries' exegetical origins in the ark of the Temple of Jerusalem, to the medieval inheritance of microarchitectural reliquary designs, and to the Jerusalemic reliquary chapel from where the relic came as locus sanctus. ${ }^{54}$ Fabricated according to a distinctly archaizing stylistic register and iconographic program, the casket presents as a three-dimensional pastiche of individual parts that appear not as the cohesive work of Prussian workshops renowned for sculpted amber artworks of the utmost modern sophistication for the period (Grabowska 1971; King 2009a). Rather, in keeping with a current in reliquary design from the Middle Ages, these variegated components imitated incongruous spolia that appear as if they were repurposed from much older objects, including florid carved appliqués, faux gems, and cabochons, and figural plaquettes (Hahn 2013). A work of early modern assemblage, the casket pretended to be pieced from much older fragments taken from other venerable sacred objects and trophies, with a distinguishing eastward-leaning Byzantinizing aura likewise typical of reliquaries in the Western medieval tradition. It conjures notions of the otherness of Lithuania's eastern neighbors and enemies and of a medieval and even antique past, which resonated with the legendary Litalinian origins of the Lithuanian aristocracy from Italy via Byzantium. ${ }^{55}$ 
While the ivory type and origin remain unknown, it could have been sourced from Nordic-Baltic or Sibero-Russian walrus for this work. Ivory was a substance with a long historical association with devotion, also avidly collected by the Medici, and often featured together with amber in Baltic-made pieces of the period. ${ }^{56}$ In the context of this object, its style and placement evoke medieval Byzantine ivory caskets often repurposed as reliquaries (Cutler 1984-1985). Ivory's snowy color invoked notions of purity and incorruption often associated with the divine in medieval sculpture and was ideally suited to rendering corporal flesh. The substance's resemblance to bone and indexical gesture to its own living origins reflexively summoned Christ's incarnation, saintly incorruption, and the promise of bodily resurrection. ${ }^{57}$ Here, it appeared in twenty-five carved relief vignettes illustrating Biblical episodes of the incarnation (Annunciation, Visitation) and portraying early Christian and medieval saints (Lawrence, Francis, Christine, Barbara, Margaret of Antioch, Catherine of Alexandria), as well as winged cherubim. Pairs of addossed figures of evangelists (Peter or Paul and John) and early bishops (Augustine and Ambrose) guard the front opening and verso. Their stiff frontal posture and linear carving evokes medieval architectural sculpture. The spiral Solomonic columns at the four corners miniaturized a signature feature of Baroque sacral architecture associated with Constantinian Rome (Ward-Perkins 1952). (Figures 8 and 9).

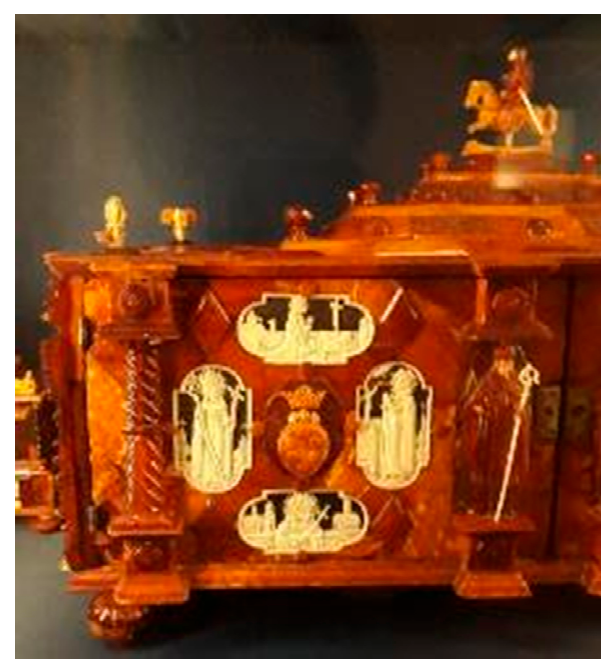

Figure 8. Danzig workshop, Reliquary of St. Kazimierz Jagiellończyk, c. 1677-1678 (left detail). Palazzo Pitti (Tesoro dei Granduchi), Florence. Photo by the author.

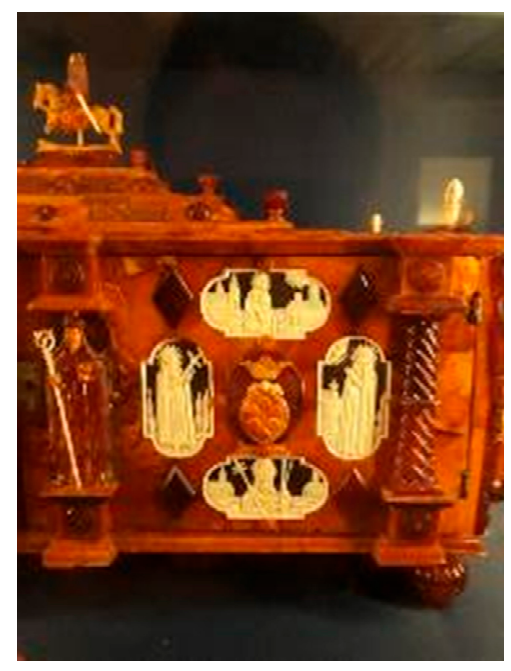

Figure 9. Danzig workshop, Reliquary of St. Kazimierz Jagiellończyk, c. 1677-1678 (right detail). Palazzo Pitti (Tesoro dei Granduchi), Florence. Photo by the author. 
The Baltic casket's mode of re-contextualizing fragmentary pseudo-originals within a palimpsestic pastiche inflected medieval Byzantine and Western forms in patently Baltic materials, relating to the past in form, style, and language, and thematizing the temporal passage between venerable and modern in a way that reanimated the grandeur of the Sarmatian past and Jagiellończyk's Litalinian origins in honor of both dynasties implicated in the relic exchange. Their shared magnificence and munificence were punctuated by reliefs of the so-called palle, the Medici escutcheon comprised six balls. Four fleur-de-lis finials on the corners were equally evocative of the Pacowie Gozdawa (lily) and Florentine Giglio (iris) (Czyż 2020). They were equally symbolic of the saint's special status as a white spiritual martyr, called un bianco giglio (a white iris) in period hagiography (di S. Antonio 1629 , p. 60). The reliquary's antiquarianism also invested with an aura of venerability the links interconnecting these dynasties and the cult of the saint inside, made present by the sculpted equestrian figurine of Kazimierz. His sword and shield and stiff posture recollect medieval heraldry and are reminiscent of the centuries-old Vytis emblem of the Lithuanian Grand Duchy (Galkus 2009), adumbrating his sobriquet of "noble Knight" in hagiographic literature (di S. Antonio 1629, p. 83).

That amber figured most prominently as the Kazimierz reliquary's premier material was consistent with period diplomatic gift-giving to promulgate the rare and storied substance as the patrimony of the Baltic elite (Netzer 1993; King 2014). The Medici's affinity for the prized substance manifested not only in collecting and displaying amber, engaging with it in religious practice, and incorporating it in medicines (Buchanan 2018), but also in their discursive obfuscation of its Baltic provenance (King 2014; Grusiecki 2017). By the time Cosimo received the long-awaited relic in its amber container, his family had already for over a century constructed a discursive "Italianisation" of amber, mythologizing its native peninsular origins in the Po River valley of ancient Etruria over the actuality of amber deposits on the Prussian littoral (King 2013a). That Etruria likewise represented one of the mythological seats of the Pacowie and the Medici alike points to amber's particular agentive properties as a heterotemporal and heterotopic material, imbued with the potential to retroactively reaffirm common dynastic origins and the transhistorical unity of the cult of saints. Amber's generative materiality evoked notions of deep time and the present, foreign, and local, thus translating the meaning of the Jagiellonian relic between respective contexts (Grusiecki 2017). Its material hermeneutics, inherited from the Middle Ages, made it exegetically suited to reliquaries: when handled, it underwent an invisible but sensible physical transformation triggered by and evocative of human flesh, bodying forth the presence of the saints. Amber retained warmth, conserved a static charge (amber in Greek

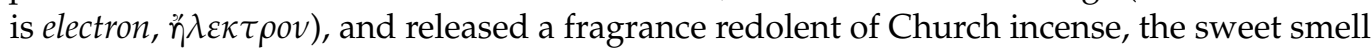
ascribed to the incorrupt bodies of saints, and the widespread expression of holy persons such as Kazimierz who died "in odor of sanctity" (King 2013b; Bouley 2017). The latter topos was extended to the miraculously preserved corpses of the Beati moderni, including Jagiellończyk, who according to hagiographers "like a white lily, which for its perfect virtue emitted a sweet odor" (di S. Antonio 1629, p. 61).

It is noteworthy that in exchange for the relic of Kazimierz, the Vilnius chapter and Bishop Pac solicited in return from the Medici a piece of the miraculously intact bodily remains of Maria Maddalena de' Pazzi from Florence, which were ultimately delivered to Vilnius in 1682 (Guidetti 2012; Maslauskaitè-Mažylienè 2018, pp. 78-79; Noyes forthcoming).$^{58}$ Hailed by Grand Duke Cosimo as the "ornament and bulwark" of the Tuscan Grand Duchy, ${ }^{59}$ Pazzi won cultic fame and official canonization after her death thanks to Medici and Pacowie patronage, and to the reported incorruption of her corpse, which was closely guarded by the nuns of the Santa Maria degli Angeli Carmelite monastery in Florence (Copeland 2016, pp. 266-75; Baniulytè 2010; Modesti 2020, pp. 225-41). At Pope Urban VIII's insistence the Carmelites had begrudged an amputated finger from their would-be saint to generate critical Vatican support for her cause (Copeland 2016, pp. 154-55), but otherwise they very rarely conceded hair or teeth as first-class relics, occasionally secondary relics such as fragments of her habit or veil, and more commonly tertiary 
relics such as ampules of lamp oil multiplied miraculously through Pazzi's intercession (Ibid., pp. 76-77). ${ }^{60}$ Records suggest that the Pacowie were already custodians of Pazzi secondary and tertiary relics that were earlier Medici gifts from Cosimo's predecessors, which they safeguarded in an eponymous chapel dedicated to the Florentine saint at Pažaislis monastery in present-day Kaunas, Lithuania, founded in 1662 by Bishop Pac's brother, Lithuanian Grand Chancellor Krzysztof Zygmunt Pac (1621-1684). ${ }^{61}$ Thus a primary relic represented a highly desirable addition to the collection of Pazzi relics under the Pacowie's safe-guardianship.

The motifs of the Pacowie Gozdawa and Florentine Giglio likewise featured prominently in the Florentine reliquary to contain Pazzi's relics for the journey north. This miniature ostensory was made of gold, enamel, rock crystal, and more than 120 diamonds in the Grand Ducal workshops within the Palazzo Pitti, the so-called Galleria dei Lavori (Gallery of Works). Under Cosimo III the Galleria promoted art and science at the highest level, bringing together pharmaceutical and alchemical laboratories with artists' workshops for the production of a range of luxury artworks executed in precious stones and metals, most notably the Opificio di Pietre Dure (Workshop for Hardstone) (Giusti 1997). Authored by Medici goldsmiths Giovanni Comparini and Giuseppe Vanni, at a mere $13 \mathrm{~cm}$ high, the Pazzi reliquary (today in the Vilnius Church Heritage Museum) was less than half the height of the amber casket of Jagiellończyk. The relics' almost imperceptible presence within the crystal globe is attested by the enamel inscription on the crowning banderol, DENS ET CAPILLI S[ANCTAE] MARIAE MAGD[ALENAE] DE PAZZI (TOOTH AND HAIRS OF SAINT MARIA MADDALENA DE' PAZZI). Despite its small size, this tour-de-force of the Medici Galleria showcased a range of metallurgical and lapidary techniques. Its material and technical manufacture entered into a kind of discursive conversation with the Kazimierz reliquary, disclosing the floral forms sublimated in the latter's baroque Solomonic columns and translating its inherent architectonic monumentality into a diminutive florid style and floral iconography (Figure 10).

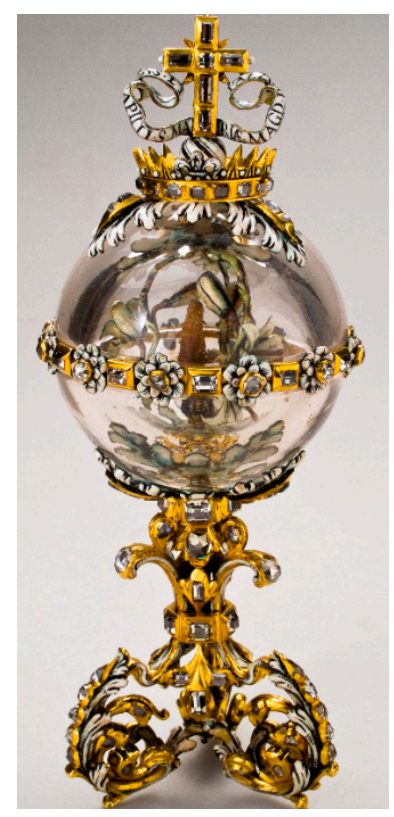

Figure 10. Giovanni Comparini, Giuseppe Vanni, Giuseppe Antonio Torricelli, and Grand Ducal Galleria. Reliquary of St. Maria Maddalena de' Pazzi, 1682. Church Heritage Museum, Vilnius. Image in the public domain.

Enamel covers much of the gold's surface as floral and vegetal motifs, including three-dimensional enamel lilies framing a single tooth and entwined with faint hairs, crown, fleur-de-lis, banderol, and cross, all encrusted with faceted diamonds. Diamonds in this period were imported from India (Teles e Cunha 2001; Hofmeester 2016), where the 
Medici projected their own imperial aspirations, supporting mercantile agents to procure the precious stones (traded through Livorno (Trivellato 2000)), as well as importing and exporting luxury materials and objects, sponsoring works of art, and engaging with local saints' cults (Freddolini 2020; Benay 2020). The monstrance defending and displaying Pazzi's fragmentary avatars seemingly blooms from the stem surmounted by a petal-like capital. Composed of two hemispheres, its translucent globe looks like glass, but was in fact sculpted from the clearest quartz (also called rock crystal), likely by Medici court lapidary Giuseppe Antonio Torricelli. Trained in the glyptic arts associated with Roman antiquity, Torricelli helped stage their revival the Galleria to produce crystal clear stone reliquary receptacles that imitated venerable spolia, thereby translating the Baltic amber casket's antiquarianism into materials linked to Medici extended dominion (Giusti 2003; Arbeteta 2016). Together these gems articulated the tiny trophy's resonances with themes of war, conquest, and crusader rhetoric surrounding the mutual exchange of relics. These meanings were most pointedly captured in the Greek term for diamond, $\alpha \delta \dot{\alpha} \mu \alpha \varsigma$ or adámas (unconquerable, invincible).

Diamonds and rock crystal, like amber, were thought to be aqueous in origin and essence (King 2009b). Following ancient sources such as Pliny's Natural History, early modern gemology held that all precious stones were formed of congealed liquid under the earth's surface. Quartz or rock crystal constituted a special case, as it formed of the purest water deeply frozen as ice and over time converted into a hard limpid mineral (Mottana 2006). Conversely, the enamel was rendered by fusing ground glass to a metal substrate in imitation of precious stones, thereby recapitulating in reverse these natural processes by means of a technically demanding medium long associated with exegesis of the Divine "refiner's fire" and used for centuries in ecclesiastical objects and reliquaries (Boehm and Taburet-Delahaye 1996). The etymological derivation of the term crystal from the

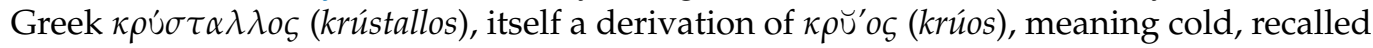
quartz's cryogenic formation and its place in period humoral theory as a "cold" substance complimentary to "warm" amber. The stones' substance thus ontologized the female humoral state proper to its saint and the frigid climate of the gift's Baltic destination, while also hinting at the Pazzi relics' numinous fertile potential to overcome-even conquertheir sex and the inhospitable environment of their future home and disseminate the saint's fame and aura in the north. The tiny ostensory that Cosimo dispatched in 1682 thus constituted a rejoinder to Ferreri's claims for the fecundity of the Jagiellonian relics in his hagiography.

Both reliquaries' haptic and thermal material facture, construed as essentially labile and shifting, not only represented and bodied forth the transitions and elisions from emotion to emotion that were intrinsic to the ecstasies of the white martyrs renowned for their ecstatic mystical episode enclosed within, but also monitored, measured, and mirrored the emotional malleability of the pious devotee who interacted physically with the relics. Furthermore, they instantiated changing period notions regarding cultural differences between south-western Europe and its north-eastern borderlands, and the possibility of particularly transregional kinds of numinosity and sanctity. Likewise, the distinctive facture of both reliquaries resonated with Counter-Reformation lapidary and bodily models of hagiography, reifying the Pauline invocation (I Peter 2:4-8) of the saints as "living stones" pieced together like a mosaic into a virtual edifice, the Celestial Jerusalem, constructed from the bodies of the saints themselves and representative of the transhistorical institution of the Church founded on Christ as cornerstone, an edifice simultaneously realized at the end of human history and existing eternally beyond it (Tutino 2013; Noyes 2018).

The Gozdawa-Giglio motif reappeared yet again on a much grander scale in a second reliquary produced for Cosimo in the Medici Galleria to re-house Jagiellończyk's relic. (Figure 11). Conceived as a massive ostensory fabricated by Medici court goldsmith Massimiliano Soldani Benzi (1656-1740), the reliquary was completed by 1687, but required another year in the gilder's workshop (Guidetti 2012; Gennaioli and Sframeli 2014, pp. 268-69; Maslauskaitè-Mažylienè 2018, pp. 67-79). ${ }^{62}$ At an immense $85 \mathrm{~cm}$ high, it towered 
more than twice the height of the amber casket it replaced and over six times that of the diminutive monstrance for the Pazzi relics. In contrast to the Prussian workshop's palimpsestic assemblage of counterfeit spolia, the Galleria's work in 1687-1688 evinced a markedly more integrated physical and stylistic concept, though not without its own medievalizing archaisms, here translated into a late Baroque language of forms rendered in supple silver and gold.

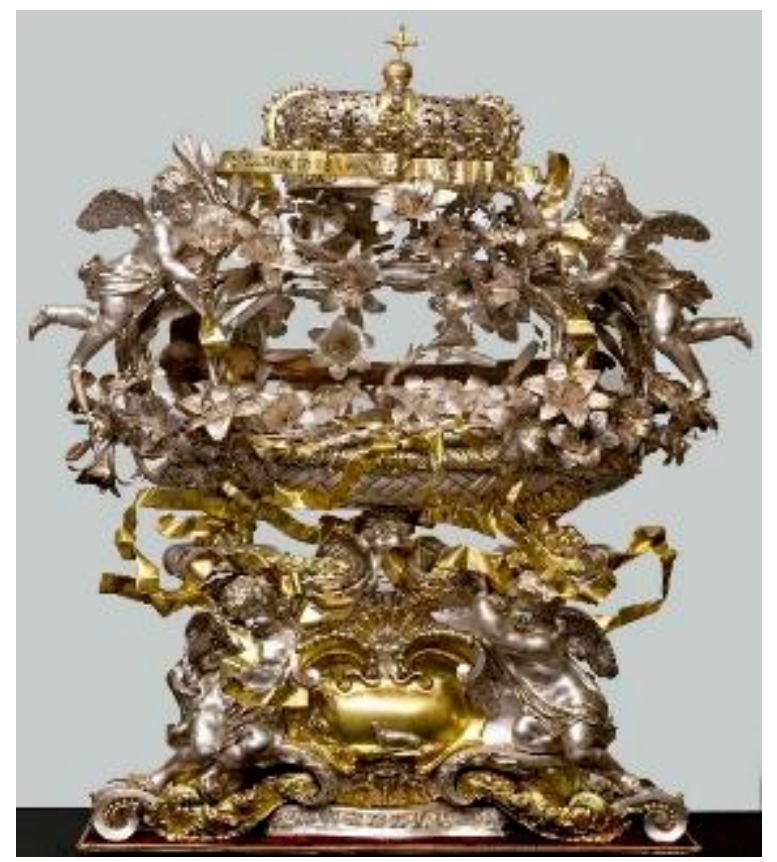

Figure 11. Massimo Soldani Benzi and Grand Ducal Galleria, Reliquary of St. Kazimierz Jagiellończyk, 1687-1688. Museo delle Cappelle Medicee, Church of San Lorenzo, Florence. Image in the public domain.

It should be underscored, however, that despite being replaced, the first amber reliquary stayed in the Cappella delle Reliquie, where it could be contemplated together with its successor. This suggests that the precious Baltic casket remained valuable not only for its precious materiality, exceptional facture, and ostensible oldness, but also for a sacral or numinous charge transferred to and conserved within the object's very substance. This translated the container it into a relic per se by virtue of contact with the prince's bone, which was exceptional per se insofar as it not only represented according to Church tradition and canon law both a primary and insignes (i.e., a major body part) relic, and was thus especially precious for the proximity it promised to the divine, but also derived from a saint whose holiness had been especially constituted through the reputed incorrupt corporeal integrity of his bodily remains after death.

Cosimo's reasons for supplanting one traditional medieval reliquary form-the casket or coffin-with another-the ostensory or monstrance-remain unclear. Increased visual access to the saint's remains (a point discussed in the Conclusion below) may have been a factor, as a number of Medici reliquaries from his tenure were designed to maximize, mediate and thematize their contents' visibility, likely catering to the grand duke's zealously devout gaze (see e.g., Gennaioli and Sframeli 2014, pp. 248-65). While the cherubim and flanking angels similarly adumbrated the Jerusalem ark, its structure subtly translated the architectonic overtones of the first amber casket by means of the application of a foundational structure composed of a velvet-covered wooden base supporting a tangled configuration of florid volutes, freely adapted from contemporary architectural elements. The base, flanked by a pair of putti and surmounted by a cherubim head, upholds a secondary structure consisting of a slim platform ornamented with triumphal laurel swagssymbol of military victory-zoomorphic clawed feet that sprout acanthus leaves, and a 
shallow woven basket seemingly plaited from silver strips. From the basket blossoms an explosion of finely crafted trompe-l'oeil silver lilies in full bloom, a tripartite reference to Kazimierz's bloodless martyrdom and Medici-Pacowie heraldica. The large skeletal fragment contrasts starkly against its lavish gleaming metallic surround, resting on a bed of naturalistic flora and overgrown with lilies, with some flowers even appearing to sprout from the relic itself (Figure 12).

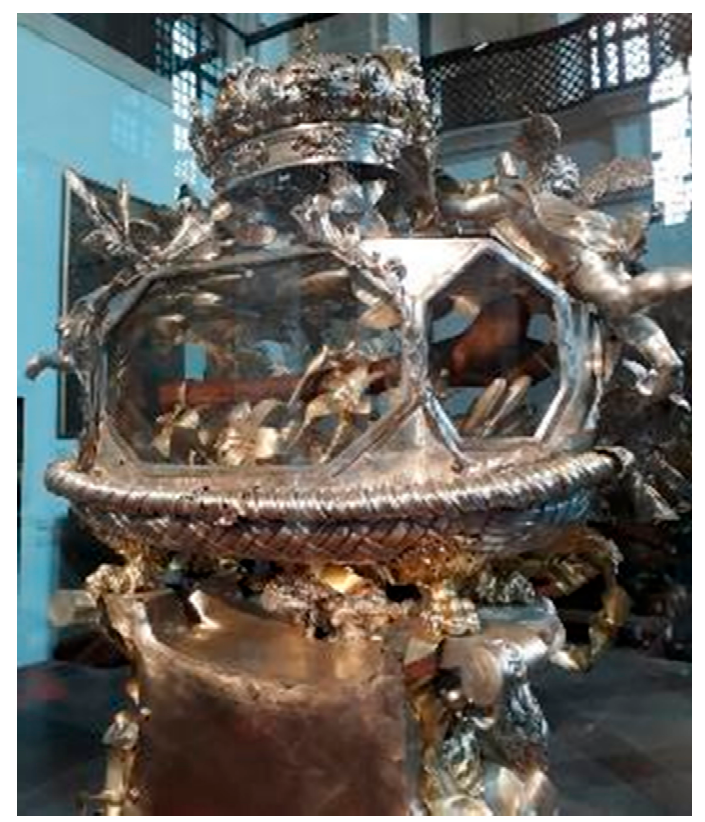

Figure 12. Massimo Soldani Benzi and Grand Ducal Galleria, Reliquary of St. Kazimierz Jagiellończyk, 1687-1688 (rear view). Museo delle Cappelle Medicee, Church of San Lorenzo, Florence. Photo by the author.

The visual and material disjunction between unadorned bone and highly wrought metal bespeaks the reliquary's presentation of the relic in the manner of spolia, borrowing presentation strategies from period Kunstkammer collections for re-contextualizing items of naturalia and exotica within finely worked luxury frames and surrounds, a technique itself adopted from medieval reliquary designs (Hahn 2013; Kazan and Higham 2019). Thus, the mode of spoliation instantiated in the first Danzig reliquary was in the second Florentine reliquary reiterated not by means of the style and facture of the container itself, but rather articulated through the relationship between worked material and the relic within. The martial themes of crusade and conquest reified in the first equestrian figure of Jagiellończyk as warring knight were sublimated in the second through the reconfiguration of the relic's triumphant trophy-like display. Seemingly upheld by a second pair of hovering putti, the ensemble is surmounted by a banderole inscribed S. CASIMIRUS MAGNUS DUX LITHUANIAE and the artist's interpretation of the Lithuanian grand ducal crown, its florid ornament echoing the prince's robe in Ferreri's woodcut portrait. Benzi's overall design with a profusion of botanical motifs and forms framing Kazimierz's "purest bone" amidst a harvest of blooms concretized Ferreri's evocation of the saint as embodied Sarmatian "tree of life, yielding the sweetest fruit of virtue and honor."

The inscription MALO MORI QUAM FOEDARI (DEATH RATHER THAN DISHONOR) on a second banderole hovering between the basket and the base echoed the first attribution in Ferreri's Vita Casimiri of this chivalric motto to Kazimierz, an association repeated in subsequent hagiography (di S. Antonio 1629, pp. 60-61) (Figure 13). Furthermore, the cartouche with an ermine on the base represented Ferreri's epithet describing the saint as a "pure ermine," a sobriquet likewise reiterated in seventeenth-century sources which claimed, "hence it is very proper to attribute to this mystical ermine the adage Magis mori, quam foedari" (di S. Antonio 1629, pp. 60-62). While perhaps surprising today, this 
association of holy prince and bloodless martyr with the white-furred creature from the mustelid family drew on long-held premodern knowledge that understood the ermine as a multivalent symbol of purity and fecundity. Natural histories maintained the perspicacious animals would rather die than sully their pure white coats. Their proclivity to rapid and capacious reproduction notwithstanding the cold and barren climate of their originary natural habitats in Baltic and far northern Europe made them sought-after fertility talismans amongst elites across Europe (Clark 2018, pp. 158-207).

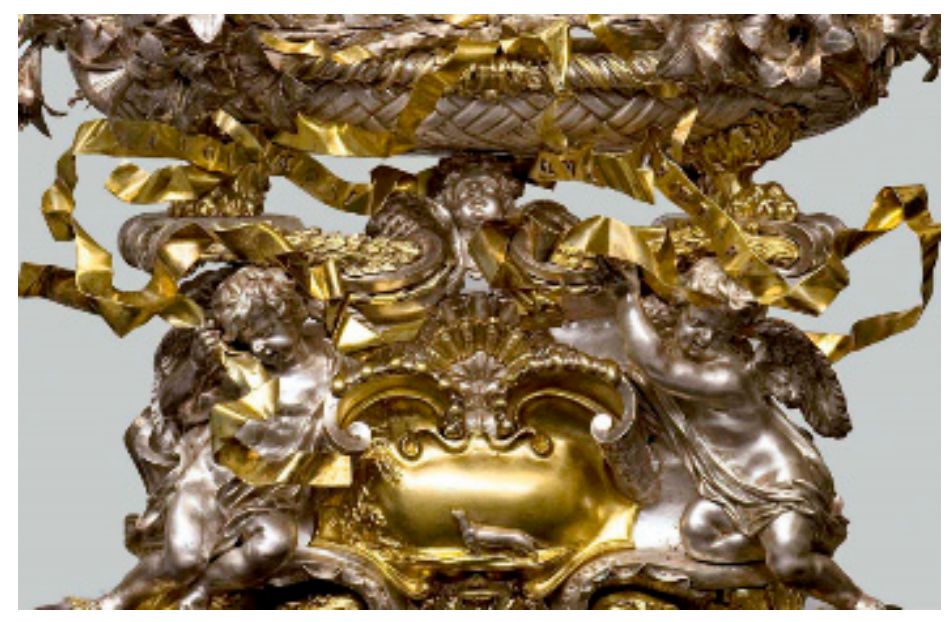

Figure 13. Massimo Soldani Benzi and grand ducal Galleria, Reliquary of St. Kazimierz Jagiellończyk, 1687-1688 (detail). Museo delle Cappelle Medicee, Church of San Lorenzo, Florence. Image in the public domain.

This, in turn, recalled the geographic source of their prized pelts for European regalia. Procured from Siberia and brokered through the Baltic Sea ports, sable, and ermine both alive and as pelts were intrinsically linked to the history of western European colonization of and relations with the Baltic, since the Middle Ages fueled by robust trade in furs (Martin 1986; Noonan and Kovalev 2004; Etkind 2011). Notably, the Pacowie had gifted the Medici a number of live sable or ermine in $1679 .{ }^{63}$ Fashioned into the Tuscan grand ducal coronation robes ornamented with over 70 dangling black-tipped ermine tales and so-called zibellini accessories worn to guarantee pregnancy and safe childbirth, their pelts bodied forth the promise of dynastic longevity. ${ }^{64}$ Medici women even prescribed amongst themselves "a girdle made of an animal from Poland, which has allowed many women who were in danger of miscarriage to give birth successfully," almost certainly just such a fur piece (Barker 2015). This suggests Medici interest in the ermine as symbol and sign redounded not only upon Kazimierz's sanctity, but also the dynasty's own prospects, thus yoking the horizons of both grand ducal lines.

Furthermore, key elements of the reliquary's iconography-including the crown, motto, and ermine cartouche-were specifically adapted from a more than 100-year-old Florentine source. This was the sixteenth-century impresa published by Tuscan polymath and Medici client Paolo Giovio (1483-1552) in his highly popular emblem compendium, Dialogo dell'imprese (Dialogue on imprese) (Giovio 1574, pp. 36-37) (Figure 14). Notably, Giovio served Medici Pope Leo X, the same pontiff widely (if incorrectly) credited with Jagiellończyk's canonization, thus plaiting a chain of patronage and piety recapitulated in the monstrance to re-house the Sarmatian prince's relic. The woodcut illustration in Dialogo portrayed the trapping of an ermine by means of surrounding it within an enclosure of dung and muck that it would not deign to touch. 


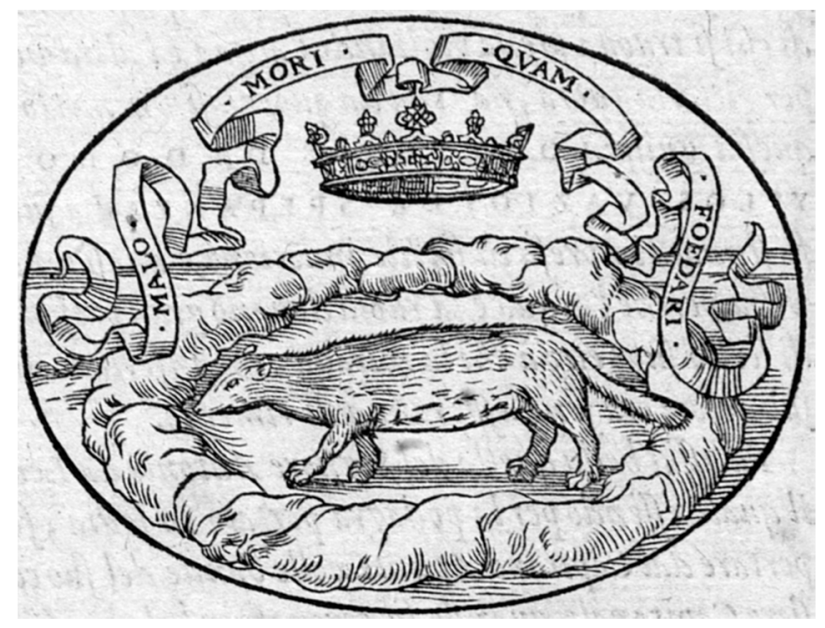

Figure 14. Impresa of the ermine (MALO MORI QUAM FOEDARI), c. 1574. In (Giovio 1574). Image in the public domain.

Likely for reasons of decorum, Benzi's cartouche adapted this design by eliminating the indecorously filthy trap and setting the noble animal against a minimalist landscape. Further elevating the motif was the fact that Giovio's exposition of the ermine impresa linked its invention to the founding of the aristocratic chivalric Order of the Ermine by King Ferrante of Naples in 1465, in an act of reconciliation and clemency following his suppression of a rebellion by a treacherous family member (Clark 2018, pp. 158-207). This association was significant insofar as it recalled the narrative of betrayal and reconciliation invented between the Pacowie and Medici. The reliquary and the Litalinian saint within thus bodied forth a Tuscan-Lithuanian revisionist history of transregional and transgenerational rapprochement, as if the exchange of holy envoys had after centuries formalized peace between the two dynasties and their respective realms.

Silver, the predominant material in the Medicean reliquary, was worked under Benzi in the Galleria according to the techniques of casting, chasing, engraving, repoussé, and gilding. As noble metals resistant to merging with lead during assaying, both gold and silver denoted privilege and purity, while the processes of refining and working these precious metals recalled Christ's refining fire (Malachi 3:2-3) and the purified souls of white martyrs like Kazimierz (Hills 2016, p. 461). Silver thus offered a fitting analogue to amber as a substance associated with holiness and the divine, thanks in part to their sensorial qualities: haptic as well as galvanic, both reacted to and conserved human energy transferred through physical contact by conducting heat; while amber released a heavenly perfume, shimmering silver reflected what St Augustine termed the lustre of saints' virtue, described as a "white" metal in early modern writings. Prized for its ductility and malleability, silver evinced qualities of ostensible liquidity that paralleled amber's purportedly aqueous origins. ${ }^{65}$

Silver was the premier material for instantiating sanctity in Italian reliquaries of the mid-to-late-seventeenth century not only for reasons of its exegetical polyvalence, but also due to its prevalence (indeed near-ubiquity) as the premier commodity of CounterReformation imperialism and of lifeblood exchange in the early modern world. Silver thus materialized the transactional essence subsumed in relics' relation to the divine more generally, as well as the particular Medici-Pacowie transactional history attending the Kazimierz relic specifically (Flynn and Giráldez 1995; Moore 2010a; Hills 2020). Although by the time Benzi produced this reliquary silver was overwhelmingly sourced via Spanish colonial networks in the Americas (Moore 2010c), the recourse to silver would have recalled how from the Middle Ages through the sixteenth century the south-after metal was mostly mined in north-central Europe, including territories over which the young Prince Jagiellończyk had been destined to rule. The heyday of this mining activity coincided with Kazimierz's short lifetime (Nef 1941; Batizi 2018). What is more, early modern intelligence 
regarding vast reserves of silver supposedly hidden underground in the wilds of Siberia drove an upsurge of neo-crusader colonial interest in the region during this period that rivalled exploitation of the fur trade (Kudachinova 2019). Although the rumored Siberian silver never materialized, the prospect of the Baltic as an alternative point of access to the precious substance should not be underestimated, particularly for realms such as Medicean Tuscany that had otherwise failed to capitalize on the great silver rush in the Americas. As a fluid "material which possessed remarkable capacity for movement, exchange, and vitality" (Hills 2016, p. 457), silver like amber offered itself as a geographically and temporally labile substance whose very material intrinsically obfuscated its own origins, promising a material means to elide the histories and spatial trajectories and entanglements of the Sarmatian saint and the lineages and dominions of the noble families mutually implicated in his "purest bones."

\section{Conclusions: "Relic States"}

Driven perhaps by both familial piety and personal devotional praxis, as well as an urge to set his own Galleria into conversation with the masterful Danzig workshops so as to translate the meaning of the first Baltic casket into a patently Tuscan aesthetic lexicon of styles and forms, Cosimo created a reliquary that facilitated beholders' ocular access to the relics within. He also further fragmented the economy of the Lithuanian relic by dividing and multiplying its containers and exposing its own fragmentariness. In doing so, however, the grand duke inadvertently disclosed the paradoxical reality of the fragility and potential ruination that threatened to undo the hagiographic discourse fashioned over more than a century around the cultic figure of the saint involved in his exchange with the Pacowie. This was a reality that Kazimierz's opaque amber casket and Palloni's fresco in the Vilnius Cathedral reliquary chapel attempted to obfuscate. In fact, the miraculous corporal state of the Sarmatian prince was neither without contest nor without threat. The reality of multiple rushed relocations of Jagiellończyk's corpse during mid-century military conflicts that ravaged the Polish-Lithuanian Commonwealth had reduced his relics from miraculously intact to fragmentary, which may be one reason why the cathedral chapter was so reticent to re-open the reliquary casket containing what was left of him (Briedis 2008, pp. 55-56). Similarly, Pazzi's corpse was subjected to repeated expert autopsies, and questions surrounded the supernatural nature of its preservation, with some suggesting that the Florentine nuns had secretly embalmed the remains. Skepticism surrounding her body was so great that the remains became a target of derision by Protestants (Bouley 2017, pp. 105-8).

On another level, both the dynasties involved in the saint's translatio and their respective realms faced existential threats to their cohesion, stability, and longevity during the same years when they arranged the relics' transfer. In designating the newly united Rzeczpospolita as "European Sarmatia," Pograbka had mapped the Commonwealth onto ancient cartographic contours, thereby historically sanctioning the recent alliance and endowing the conglomerate nation's heterogeneous szlachta with a common assimilated heritage by virtue of bootstrapping its authoritative classical pedigree, a strategy in keeping with period humanist historiographical practices widespread throughout Europe (Girkus and Lukoševičius 2012; Grusiecki forthcoming). The Jagiellonian relic called to mind that in converting to Christianity in 1386 and initially forging an united (if only loosely) Poland-Lithuania, Jogaila had initiated a dynasty that would dominate much of politics in east-central Europe for two centuries and christened Lithuania a Christian (and later Roman Catholic) state. Despite the Pacowie's championing of their house and the Lithuanian Grand Duchy as bastions of Roman Catholicism, in reality, its diverse population numbered (among others) Ruthenians (Belarusians and Ukrainians), Poles, Lithuanians, and Germans of various confessions, as well as Jews, Tatars, and Cossacks (Frick 2013). ${ }^{66}$ In negotiating through "relic diplomacy" with the Medici, the Pacowie were realigning their interests within a religiously divided polity and within greater Catholic Europe, even as the Commonwealth reeled from the series of mid-seventeenth-century Swedish and 
Russian military campaigns collectively known as the Deluge that wreaked destruction on Kazimierz's holy chapel and body (Frost 1993). Concurrently, their own house faced discontinuation: neither Bishop Pac (who had divorced in order to assume the episcopate) nor his cousin Hetman Pac (who never married) perpetuated the Pacowie line.

Cosimo's jubilant letters over receiving Kazimierz's relics were inflected by rhetorical concepts of crusade and pilgrimage, reflecting the Medici's awareness and appropriation of this medieval legacy for their own house as a pious lens through which to project his line's interests in the north, even as the colonial ambitions of the relatively minor power of the Tuscan Grand Duchy were outpaced on the global stage and their bloodline approached extinction (Markey 2016; Brege 2017). The grand duke and his wife Marguerite Louise d'Orléans had separated irreparably in 1675 , and he would be the Medici's last viable male heir, while his personal pious pursuit of sanctity begat a costly lifelong compulsion for expensive commissions of luxury sacral artworks that contributed to Tuscany's financial decline (Acton 1988).

Within this transcultural context of imperial aspiration and dynastic fragmentation and discontinuation, the crucial stabilizing role of the discursive medievalization of St. Kazimierz Jagiellończyk, ultimately materialized and reconstituted by his reliquaries, constituted a crucial bond amongst networks of mutual exchange and reciprocation within and between Tuscan and Lithuanian constituencies, while also critically reaffirming the vaunted integrity of their holy mediator. While Counter-Reformation constituencies (including the Pacowie and Medici) involved in the refashioning of the prince may not have perceived the Jagiellonian cult as medieval per se, but rather as venerable or even ancient, this re-temporalization invested both the cult and its devotees with the illustrious glimmer of deep-rooted history and seemingly longer-reaching time. Such a shift undertook the discursive forging of an unbroken chain stretching backward along the axis of human chronology through the special potency of relics of vaunted integral saints such as Kazimierz to re-embody Italy's connection to the Baltic and re-affirm the Pacowie and Medici dynasties' mythological origins and professed long-standing interwoven histories. This points to a mode of relationality between saint and state, such that the translations of the status, artistic framing, and conditions of the saint and his body might be mapped against the transformations undergone by the Lithuanian and Tuscan realms, throughout the emergence, endurance, and disaggregation of both, evincing the representational labor that such translated cults and corpses perform over time in the space of ritual, wherein the fragile state of saint and state might be masked by a variety of media and measures. ${ }^{67}$

Funding: Research for this article has received funding from the European Union's Horizon 2020 research and innovation program under the Marie Sklodowska-Curie grant agreement No. 842830 (TRANSLATIO), hosted by the National Museum of Denmark. Additional support for field research has been generously provided by the following: Archimedes Estophilus Estonian National Scholarship, Böckler-Mare-Balticum-Stiftung Travel Grant, Fritz Thyssen Stiftung Travel Grant, and Latvian State Fellowship for Research. Bourse Robert Klein (Kunsthistorisches Institut Florenz-INHA Paris-Villa Finaly Chancellerie des Universités de Paris-Sorbonne)

Institutional Review Board Statement: Not applicable.

Informed Consent Statement: Not applicable.

Data Availability Statement: Not applicable.

Conflicts of Interest: The author declares no conflict of interest.

\section{Notes}

Aspects of research towards this article were presented at the following international conferences and workshops: "Performing Gifts. Rituals, Symbolic Communication and Gift-Giving in Medieval and Early Modern Europe" (Tallinn University, 2019), "Annual Meeting of the Renaissance Society of America" (2021), "The Noble Family of Pacowie (Pacai) of the Grand Duchy of Lithuania and Lithuanian Baroque" (Kaunas, 2021), "Sacred Books, Holy Relics and Godly Women: New Perspectives on Sanctity 
in Renaissance Europe. New trends in the humanities seminar series" (University of Oslo, 2021). Sincere thanks to Nils Holger Petersen for insights and support towards the preparation of this article, and to the Religions reviewers for valuable feedback.

Adapted from translations in (Briedis 2008, p. 38 and Dini 2014, p. 50). Unless otherwise specified, all translations are the author's own. For the Krakow edition of Vita Beati Casimiri Confessoris see e.g., Rome, Biblioteca Nazionale, 14. 28.C.31.1. An edition was also published in Torún: see e.g., Lublin, Biblioteka Uniwersytecka KUL, XVI.499. For a composite copy with material from both editions see Krakow, Biblioteka Jagiellońska, BJ St. Dr. Cim. 4858.

3 On Ferreri see (Stöve 1996) and further citations below.

4 On the history of the cult of St. Kazimierz with special attention to the Italo-Lithuanian sphere see (Maslauskaitè-Mažylienè 2010, 2013).

5 For overviews of Lithuania in the premodern era see (Kiaupa et al. 2000; Davies 2013).

$6 \quad$ For relic translatio in the period under discussion here, see (Achermann 1981; Hills 2016); more generally, see (Heinzelmann 2002).

7 “Dat Casimiri lucida/Dies cupita gaudia /et italis, et sarmatis, /accepit unde originem ... Mori magis, quam transgredi/ Pudicitatis limitem ... Tu puritatis lilium ... Tuum genus defendito/Contra furores bellicos, /Contra scytas, et impias/ Sectas, et al. tra schismata ...." In (Ferreri 1521a, n.p.).

8 On Reformation tensions in the Rzeczpospolita during this early period see (Nowakowska 2014; Kriegseisen et al. 2016, pp. 319-413). More broadly, Ferreri took part in reforming the Breviary, and published an oration on Church reforms (Ferreri 1523) that was later republished by the Tridentine Council (Stöve 1996). In (Nowakowska 2014, p. 57).

10 For more on the saint's woodcut portrait see further discussion below.

11 On the long history of spiritual martyrdom see (Rush 1962).

12 See also (Dini 2010).

13 See e.g., (Suchocki 1987; Jučas 1994; Baniulytè 2012; Orzeł 2019).

"Lithuanos [ ... ] Latini generis esse, etsi non a Romanis, saltem ab aliqua gente Latini nominis descendisse ... ." Although Długosz's work was published in the seventeenth century, it circulated widely in manuscript during the prior century: see (Długosz 1615). On Długosz see (Papée 1939-1946; Knoll 1982).

On the history of this order see (Urban 2003); with reference to Lithuania (Petrauskas 2012).

On the Lithuanian crusades from the thirteenth century see (Murray 2010; Petrauskas 2012).

See (Długosz 1981).

See also: "Moscovitae irati imprecantur alicui suorum, us fiat Romanae sive Polonicae religionis. adeo eam exosam habent. Gymnasiis literatiis, dolendum, caremus. literas Moscoviticas nihil antiquitatis complectentes, nullam ad virtutem efficaciam habentas ediscimus, cum idioma Ruthenum alienum sit a Nobis Lithuanis, hoc est, Italico Sanguine oriundis." (Angry Muscovites, they call down on any of their followers, be it Roman or Polish religion. they hate her so much. Unfortunately, we lack literary schools. We learn from the Muscovite letters which have no antiquity, and have no efficacy, we learn, since the Russian language is foreign to us from Lithuanians, that is, originating from the Italian blood.) In (Lituanos 1615, p. 23). See (Orzeł 2010).

On Pograbka see (Hajdukiewicz 1982-1983).

(Jerzy 1987).

See e.g., (Guagnini 1581, pp. 45r-v). On the author see (Ronchi De Michelis 2003).

See e.g., Historiae Lituanae (History of Lithuania) by Jesuit and Deputy Vice Chancellor of Lithuania Albert (Wojciech) Wijuk Kojałowicz (1609-1677) (Wijuk Kojałowicz 1650, pp. 28-47), and further examples below.

For the Medici's promotion of the Pazzi cult see (Copeland 2016; Modesti 2020, pp. 225-41). For the Lithuanian context see (Baniulytè 2010).)

For this historicizing see especially the scholarship of A. Baniulytė, including (Baniulyte 2003, 2005b, 2007, 2009).

e.g., papal nuncio in Poland-Lithuania Pietro Vidoni (1611-1681) wrote to Rome in 1654 of Lithuanian grand marshal Kristof Pac (1621-1684), whom he called "Christoforo de Pazzi," that "che reale origine [era] da quella di Firenze" (his real origin is from Florence). See Rome, Archivio Segreto Vaticano (ASV), Nunziatura di Polonia, vol. 62, fols. 323v-324r. On Stefan Pac see (Czapliński 1979).

Rome, Archivum Romanum Societatis Iesu (hereafter ARSI), Epistolae Externorum, vol. 36, fol. 1r-v. For relevant archival sources pertaining to the exchanges taken up in the ensuing sections of this article see records preserved in Florence, Archivio di Stato Firenze (hereafter ASF), f. Mediceo del Principato: 1529-1753 (hereafter MP), 4489-4494, especially 4492, 298r-v, 442r-v, 561r, 604r, 697r; 4493, 602r-v, 603-604, 608r-v, 609r-v. On Cosimo III see (Guarini 1984).

30 See also ASF, MP 4493, fols. 470r-v, 472 r-v, 602r-v.

31 On Bishop Pac see (Rachuba 1979). 
Pacowie relations with Italy and Medicean Tuscany have been taken up in a number of important multilingual studies by Aušra Baniulytė and Anna Sylwia Czyż cited below and throughout this essay. See also (Rachuba 1979).

On the history of this order see (Urban 2003).

For published period primary sources related to Italian promotion of Casimir's cult see (di S. Antonio 1629; Rosselli 1642; Sobecki 1674; Skarbek 1684).

For aspects of Italo-Baltic historical relations during the Middle Ages and Early Modern eras, see (Brahmer 1980; Lewanski 1994; Baniulyte 2005a; Bugiani 2007; Mitrulevičiūtè 2016; Guidetti 2018), and additional citations below.

The painting's notoriety is suggested by the fact that Dolci made a copy of the work, which is illustrated here.

For an overview of the Baltic crusades see also (Murray 2001).

For studies in Baltic cultural geography see (Tamm 2009) and other studies in (Murray 2009). For connections between the Holy See and Poland-Lithuania in this period see (Platania 1992, 2000, 2011).

For the topos of Antemurale Christianitatis see (Srodecki 2015; Rowell 2002). For the topoi of "womb of nations" and "indies of Europe" see, respectively, (Donecker 2018) and (Morawski 1989; Caccamo 2010; Donecker 2016). On the Baltic as commodity frontier see (Moore 2010a, 2010b). For Baltic biodiversity see (Jørgensen 2018); on the fur trade see (Martin 1986). For the rumored but never realized prospect of precious metals in the region see (Kudachinova 2019).

For early hagiography of Kostka in Italy, see (Sacchini 1610a, 1610b); for Kuncewicz, see (Gerardi 1643; Borovio 1644; Susza 1665, 1666). For secondary literature on Kostka's cult in Rome (also the site of his death) see (Levy 1997); for Kuncewicz (Jobst 2012). For these circumstances and the dispersal of Kazimierz's relics see (Theatrum S. Casimiri 1604; Žygas 1996; Maslauskaite 2006). For Castelli and Tencalla see especially the work of Mariusz Karpowicz, including (Karpowicz 2002, pp. 135-53; 2003).

On the chapel design see also (Žygas 1996, 2000; Mollisi 2013, pp. 29-31; Koutny-Jones 2015, pp. 173-75). On Pac's involvement see (Jamski 2005a, p. 508). For Roman Counter-Reformation revivals of martyria, inlcuding for enshrining relics of Beati moderni, see (Noyes 2018, p. 295).

For the chapel programme see (Žygas 2000, pp. 33-35; Jamski 2005b, 2008; Czyż 2017); on the significance of the confessio see (Noyes 2018, pp. 180-81). For the confessio altar type in Poland in this period, see especially studies by Ryszard Maczyński, e.g., (Mączyński 2003, 2005).

See also Florence, ASF, MP, 4493, 430v.

For Sarmatist self-fashioning in period portraiture, including discussion of the distinguishing accoutrements and features, see (Grusiecki 2018; Guile 2018). ARSI, Epistolae Externorum, vol. 36, fol. 32r-v.

See also Florence, ASF, MP 4493, fol. 492r, 608r-v, 609r-v and Guardaroba Medicea, n. 802 Guardaroba del taglio, 594.

See Florence, Archivio della Basilica di San Lorenzo, 73.

ASF, MP 4493, fol. 609r-v.

ASF, MP, 4493, fol. 431r. For the gifts exchanged between Grand Duke Cosimo and Hetman Pac see (Le Pouésard 2019).

Echoing the recent study (Le Pouésard 2019).

For amber gifts to the Medici see (Piacenti 1966; King 2014, pp. 5-9).

On reliquaries' architectural history see (Bucher 1976); on the resonances of the Kazimierz chapel in Vilnius see (Koutny-Jones 2015, pp. 173-75).

For an exploration of linkages between spolia and relics see (Elsner 2000).

For the Nordic-Baltic region and Siberia as sources of ivory in this period see (Rijkelijkhuizen 2009); for Medici ivory collections see (Schmidt 2008, 2012). For period mixed amber-ivory objects see e.g., (Gennaioli and Sframeli 2014, p. 224; King 2014, p. 6; Grusiecki 2017, pp. 10-12).

For various approaches to these themes see (Monroe 1978; Sand 2014; Guérin 2013).

See also ASF, MP, 4493, fol. 731r-v.

Ibid.

"Primary" or "first-class" relics were distinguished according to the Catholic church from "secondary" (objects a holy person used or touched) and "tertiary" (objects in physical contact with one of the former). See (Hahn 2013, pp. 8-9). Canon Law further distinguished between significant (insignes) relics, typically a saint's entire body or a major portion thereof, and non-significant (non insignes) relics. A recent helpful theoretical overview of relics research with bibliography can be found (Kazan and Higham 2019).

Eighteenth-century inventory records for Pažaislis described a "large ebony reliquary with small silver shelves and three figurines on top, in which there are two Vella of S. Maria Magdalena de Pazzi, oil in an ampoule, a piece of gray habit." Vilnius, Wroblewskis Library of the Lithuanian Academy of Sciences, f. 43-9919, "Pažaislio vienuolyno ir bažnyčios inventorius, sudarytas 1797," 20-21. The reliquary's facture corresponds to period examples produced in the Medici workshops. See also (Baniulyte 2010, p. 234). 


\section{References}

\section{Archival Sources}

Rome, Archivum Romanum Societatis Iesu (ARSI), Epistolae Externorum, vol. 36.

Florence, Archivio di Stato Firenze (ASF), f. Mediceo del Principato: 1529-1753 (MP), 4489-4494; Guardaroba Medicea, n. 802 Guardaroba del taglio.

Florence, Archivio della Basilica di San Lorenzo, 73.

Vilnius, Wroblewskis Library of the Lithuanian Academy of Sciences, f. 43-9919, "Pažaislio vienuolyno ir bažnyčios inventorius, sudarytas 1797."

\section{Primary Sources}

Baronio, Cesare. 1586. Martyrologium Romanum ad Nouam Kalendarii Rationem, et Ecclesiasticae Historiae Veritatem Restitutum. Gregorii 13. pont. max. Iussu Editum. Rome: ex typographia Dominici Basæ.

Borovio, Filippo. 1644. Breue Racconto Del Martirio Santita Della Vita, Heroiche Virtu, E Miracoli Del Beato Giosafat Cunceuitio Arciuescouo Di Polocia Ruteno. Rome: Lodouico Grignani.

Breve apostolicum. 1602. Breve apostolicum Clementis Papae VIII super festum S. Casimiri sub duplici ritu celebrandum in universo Poloniae Regno et Magno Ducatu Lituaniae cum lectionibus et orationibus propriis. Rome: Roman Catholic Church, 1602.

di S. Antonio, Hilarione. 1629. Il Breve Compendio Della vita Morte, e Miracoli del Santissimo Prencipe Casimiro, figlio del Magno Casimiro re di Polonia, Riferita da Monsignore Zaccaria Ferrerio ... . Naples: per Aegidio Longo.

Długosz, Jan. 1615. Historia Polonica Ioannis Długossi seu Longini Canonici Cracovien in Tres Tomos Digesta. Dobromil: In officina Ioannis Szeligae.

Długosz, Jan. 1981. Roczniki czyli Kroniki stawnego Królestwa Polskiego. Księga dziesiąta 1370-1405. Translated and Edited by Stanisław Gawęda, Danuta Turkowska, Maria Kowalczyk, Julia Mruk, Józef Garbacik, Zbigniew Perzanowski, and Krystyna Pieradzka. Warsaw: Wydawnictwo Naukowe PWN.

Ercole, Domenico Antonio. 1687. Breue Compendio Della vita di S. Casimiro Confessore, Figliuolo del re di Polonia Cauata da Diuersi Autori. Rome: per Domenico Antonio Ercole.

Ferreri, Zaccaria. 1521a. Vita Beati Casimiri Confessoris: Ex Serenissimis Poloni[a]e Regibus \& Magnis ... Zacharia Ferrerio Vicentino Pontifice Gardien[se]: In Polonia[m] \& Lituania[m]. Cracow: Iohannes Haller.

Ferreri, Zaccaria. 1521b. Oratio Legati Apostolici Habita Thorunij in Prussia ad Serenissimum Poloniae Regem contra Errores Fratris Martini Lutheri. Cracow: Iohannes Haller.

Ferreri, Zaccaria. 1523. De reformatione Ecclesiæ. Suasoria r.p.d. Zachariæ Ferrerij Vicentini pontificis Gardiensis. Venice: per Io. Antonium \& fratres de Sabio.

Ferreri, Zaccaria. 1992. Zacharias Ferreri (1519-1521) et Nuntii Minores (1522-1553). Edited by Henryk Damian Wojtyska. Rome: Institutum Historicum Polonicum Romae, Fundatio Lanckoroński.

Gerardi, Antonio. 1643. Sommaria Relatione Della Vita, E Miracoli Del Beato Martire Giosafat Cunceuitio Dell'Ordine Di S. Basilio Magno. Rome: Ludouico Grignani.

Giovio, Paolo. 1574. Dialogo Dell'imprese Militari et Amorose di Monsignor Giouio Vescouo di Nocera. Lyon: appresso Guglielmo Rouillo.

Guagnini, Alessandro. 1581. Sarmatiae Europeae Descriptio, Quae Regnum Poloniae, Lituaniam, Samogitiam, Russiam, Massouiam, Prussiam, Pomeraniam, Liuoniam, et Moschouiae, Tartariaeque Partem Complectitur. Spira: apud Bernardum Albinum.

Lituanos, Michalos. 1615. Michalonis Lituani De moribus Tartarorum, Lituanorum et Moschorum, fragmina 10. Multiplici Historia Referta. Basel: apud Conradum Waldkirchium.

Lituanos, Michalos. 1642. Quaedam ad lituaniam pertinentia, ex Fragmentis Michalonis Lituani. In Respvblica; siue, Status Regni Poloniæ, Litvanix, Prossix, Livonix, etc. 1642. Leiden: Ex officina Elzeviriana, pp. 246-54.

Miechowita, Maciej. 1521. Descriptio Sarmatiarum Asianae et Europianae et eorum quae in eis continentur. Cracow: Jan Haller.

Officium S. Casimiri. 1603. Officium S. Casimiri Confessoris per totum Poloniae Regnum et magnum Lituaniae Ducatum Ex Decreto S. D. N. dementis VIII. Pont. Max. Rome: Apud Carolum Vulliettum.

Petrauskas, Rimvydas. 2012. Litauen und der Deutsche Orden: Vom Feind zum Verbündeten. In Tannenberg—Grunwald—Žalgiris 1410: Krieg und Frieden im späten Mittelalter. Edited by Werner Paravicini, Rimvydas Petrauskas and Grischa Vercamer. Wiesbaden: Harrassowitz, pp. 237-52.

Rosselli, Geronimo. 1642. Breve Compendio Della Vita, Morte, et Miracoli di S. Casimiro Dato in Luce da un Deuoto Servo del Santo. Palermo: Nicolò Bua \& Michele Portanoua. 
Sacchini, Francesco. 1610a. Vita del beato Stanislao Kostka della Compagnia di Giesu. Composta dal P. Francesco Sacchini della medesima Compagnia. Rome: Bartholomeo Zannetti.

Sacchini, Francesco. 1610b. Vita B. Stanislai Kostkae Poloni e Societatis Iesu, Auctore Francisco Sacchini Societatis eiusdem Sacerdote. Milan: Apud her. Petrimartyris Locarni, \& Io. Bapt. Bidellium.

Skarbek, Jan. 1684. Mars Gloriosus. Diuus Casimirus Poloniae Princeps, Pro Solemnitate Eiusdem Quarta Martij Celebrata, in Ecclesia Sanctissimi Saluatoris, Et Sancti Stanislai Nationis Polonae De Vrbe. Rome: Michaelis Herculis.

Sobecki, Jan Kazimierz. 1674. Virtus Regia S. Casimiri Principis Poloniae Magni Ducis Lituaniae, in Ecclesia Sancti Stanislai Nationis Polonae a Ioanne Casimiro Sobecki Panegyrica Oratione Celebrata. Rome: Varesij.

Stryjkowski, Maciej. 1582. Kronika Polska, Litewska, żmudzka i Wszystkiej Rusi (Chronicle of Poland, Lithuania, Samogitia and all of Ruthenia). Kaliningrad: Drukowano w Krolewcu: U Gerzego Osterbergera.

Susza, Jakob Jan. 1665. Cursus Vitae, et Certamen Martyrij, B. Iosaphat Kunceuicij Archiepiscopi Polocensis. Rome: Varesij.

Susza, Jakob Jan. 1666. Saulus et Paulus Ruthenae Vnionis Sanguine beati IOSAPHAT Transformatus. Rome: Varesij.

Theatrum S. Casimiri. 1604. Theatrum S. Casimiri: In quo Ipsius Prosapia, vita, Miracula, et Illustris Pompa in Solemni Eiusdem Apotheoseos Instauratione, Vilnae Lithuaniae Metropoli, V. Id. Maij, anno Domini M.DC.IV. Instituta Graphice Proponuntur ... . Vilnius: Operis typographicis Academiae Societatis Iesu.

Wijuk Kojałowicz, Albert (Wojciech). 1650. Histoirae Lituanae pars prior: De rebus Lituanorum ante susceptam Christianam Religionem ... Libri Novem. Gdansk: Sumptibus G. Försteri.

\section{Secondary Sources}

Achermann, Hans-Jakob. 1981. Translationen heiliger Leiber als barockes Phänomen. Jahrbuch für Volkskunde 4: 101-11.

Acton, Harold. 1988. The Last Medici. London: Cardinal, Sphere Books Ltd.

Arbeteta, Letizia. 2016. Arte Transparente. La Talla del Cristal en el Renacimiento Milanés. Madrid: Prado Museum.

Baniulytè, Aušra. 2003. Lietuvos Didžiosios Kunigaikštystès didikų Pacu kilmè iš Italijos: Tarp iliuzijos ir tikrovès. [The italian descent of Pacai, the Grand Duchy of Lithuania noblemen: Between illusion and reality]. In Dailè: Acta Academiae Artium Vilnensis 31. Istorine Tikrove ir Iliuzija: Lietuvos Dvasinès Kultūros šaltiniu Tyrimai. Edited by Dalia Klajumienè. Vilnius: Vilniaus dailès akademijos, pp. 103-10.

Baniulytė, Aušra. 2005a. Italai XVI-XVII a. Lietuvos Didžiosios Kunigaikštystės kasdieniame gyvenime. In Lietuvos etnologija/Lithuanian Ethnology. Edited by Auksuolè Čepaitienè. Vilnius: Lithuanian Institute of History, pp. 75-96.

Baniulytè, Aušra. 2005b. Pacai ar Pazzi? Nauja Palemono legendos versija LDK raštijoje. In Istorijos Rašymo Horizontai, Senoji Lietuvos literatūra. Edited by Aušra Jurgutienè and Sigitas Narbutas. Vilnius: Lietuvių literatūros ir tautosakos institutas, pp. 140-66.

Baniulytė, Aušra. 2007. I Pazzi di Lituania nella corrispondenza italiana del XVII secolo: Storia e onomastica. In Res Balticae: Miscellanea Italiana di Studi Baltistici. Livorno: Books \& Company, pp. 127-44.

Baniulytė, Aušra. 2009. The Pazzi Family in Lithuania: Myth and Politics in the European Court Society of the Early Modern Age. Medium Aevum Quotidianum 58: 41-57.

Baniulytè, Aušra. 2010. Šv. Marijos Magdalenos de'Pazzi kultas Lietuvos baroko kultūroje: Atvaizdai ir istorinè tikrovè. Darbai ir Dienos 53: 225-58.

Baniulytè, Aušra. 2012. Italian Intrigue in the Baltics: Myth, Faith, and Politics in the Age of the Baroque. Journal of Early Modern History 16: 23-52. [CrossRef]

Barker, Sheila. 2015. Christine de Lorraine and Medicine at the Medici Court. In Medici Women. The Making of a Dynasty in Grand Ducal Tuscany. Edited by Giovanna Benadusi and Judith C. Brown. Toronto: Centre for Renaissance and Reformation Studies, pp. 154-80.

Baronas, Darius, and S. C. Rowell, eds. 2015. The Conversion of Lithuania. From Pagan Barbarians to the Late Medieval Christians. Vilnius: Institute of Lithuanian Literature and Folklore.

Barraclough, Eleanor Rosamund, Danielle Marie Cudmore, and Stefan Donecker, eds. 2016. Imagining the supernatural north. Edmonton: University of Alberta Press.

Batizi, Zoltán. 2018. Mining in Medieval Hungary. In The Economy of Medieval Hungary. Edited by József Laszlovszky, Balázs Nagy, Péter Szabó and András Vadas. Leiden: Brill, pp. 166-81.

Benay, Erin. 2020. Of Rhinos, Peppercorns and Saints: (Re)presenting India in Medici Florence. In Art, Mobility, and Exchange in Early Modern Tuscany and Eurasia. Edited by Francesco Freddolini and Marco Musillo. New York: Routledge, pp. 121-45.

Blomkvist, Nils. 2005. The Discovery of the Baltic: The Reception of a Catholic World-System in the European North (AD 1075-1225). Leiden: Brill.

Boehm, Barbara Drake, and Elisabeth Taburet-Delahaye, eds. 1996. Enamels of Limoges, 1100-1350. New York: The Metropolitan Museum of Art.

Bouley, Bradford A. 2017. Pious Postmortems: Anatomy, Sanctity, and the Catholic Church in Early Modern Europe. Philadelphia: University of Pennsylvania Press.

Brahmer, Mieczysław. 1980. Powinowactwa Polsko-włoskie: Z Dziejów Wzajemnych Stosunków Kulturalnych. Warsaw: Państwowe Wydawnictwo Naukowe. 
Brege, Brian. 2017. Renaissance Florentines in the Tropics: Brazil, the Grand Duchy of Tuscany, and the Limits of Empire. In The New World in Early Modern Italy, 1492-1750. Edited by Elizabeth Horodowich and Lia Markey. Cambridge: Cambridge University Press, pp. 206-22.

Brege, Brian. 2020. Making a New Prince: Tuscany, the Pasha of Aleppo, and the Dream of a New Levant. In Art, Mobility, and Exchange in Early Modern Tuscany and Eurasia. Edited by Francesco Freddolini and Marco Musillo. New York: Routledge, pp. 19-32.

Briedis, Laimonas. 2008. Vilnius, City of Strangers. Vilnius: Baltos Lankos.

Buchanan, Ashley Lynn. 2018. The Politics of Medicine at the Late Medici Court: The Recipe Collection of Anna Maria Luisa de' Medici (1667-1743). Ph.D. thesis, University of South Florida, Tampa, FL, USA.

Bucher, François. 1976. Micro-Architecture as the 'Idea' of Gothic Theory and Style. Gesta 15: 71-89. [CrossRef]

Bugiani, Piero. 2007. From Innocent III to Today-Italian Interest in the Baltic. Journal of Baltic Studies 38: 255-62. [CrossRef]

Burman, Edward. 1989. Italian Dynasties: The Great Families of Italy from the Renaissance to the Present Day. Wellingborough and Northamptonshire: Equation.

Caccamo, Domenico. 2010. Le Indie d'Europa: Polonia, Ucraina, Russia nella letteratura di viaggio e di esplorazione. In Roma, Venezia e l'Europa Centro-Orientale: Ricerche Sulla Prima età Moderna. Franco Angeli: Milano, pp. 352-64.

Chojnicka, Krystyna. 2010. Romowe: Źródło Legendy O Rzymskim Rodowodzie Litwinów. In Vetera Novis Augere: Studia I Prace Dedykowane Profesorowi Wactawowi Uruszczakowi. Edited by Stanisław Grodziski, Dorota Malec, Anna Karabowicz Anna and Marek Stus. Krakow: Wydawnictwo Uniwersytetu Jagiellońskiego, pp. 85-97.

Christiansen, Eric. 2016. Le Crociate del Nord: Il Baltico e la Frontiera Cattolica: 1100-1525. Bologna: Il mulino.

Chynczewska-Hennel, Teresa. 2006. Nuncjusz I Król: Nuncjatura Maria Filonardiego W Rzeczypospolitej 1636-1643. Warsaw: Wydawnictwo "Neriton".

Clark, Leah R. 2018. Collecting Art in the Italian Renaissance Court: Objects and Exchanges. Cambridge: Cambridge University Press.

Codello, Aleksander. 1970. Hegemonia Paców na Litwie i ich wpływy w Rzeczypospolitej 1669-1674. Studia historyczne 13: 25-56.

Copeland, Clare. 2016. Maria Maddalena de' Pazzi: The Making of a Counter-Reformation Saint. Oxford: Oxford University Press.

Cutler, Anthony. 1984-1985. On Byzantine Boxes. The Journal of the Walters Art Gallery 42/43: 44-46.

Czapliński, Władysław. 1979. Pac Stefan. In Polski słownik biograficzny. Wroclaw: Zakład Narodowy im. Ossolińskich, vol. 24, pp. 748-49.

Czyż, Anna Sylwia. 2017. Kaplice św. Kazimierza i Niepokalanego Poczęcia Najświętszej Maryi Panny przy katedrze wileńskiej oczami karmelitanek bosych - nierozpoznane źródło z 1638 roku. Saeculum Christianum 24: 162-69. [CrossRef]

Czyż, Anna Sylwia. 2018. Pamięć o poprzednikach i kłótnie z kapituła, czyli o działalności biskupa Mikołaja Stefana Paca na rzecz skarbca katedry wileńskiej. Humanities and Social Sciences 23: 9-30. [CrossRef]

Czyż, Anna Sylwia. 2020. The Symbolic and Propaganda Message of the Heraldic Programmes in Two 17th-Century Marriage Prints (Epithalamia) of the Pacas Family. Knygotyra 73: 79-93. [CrossRef]

Davies, Norman. 2013. Litva: The Rise and Fall of the Grand Duchy of Lithuania: A Selection from Vanished Kingdoms. New York: Penguin.

Dilke, O. A. W. 1984. Geographical Perceptions of the North in Pomponius Mela and Ptolemy. Arctic 37: 347-51. [CrossRef]

Dini, Pietro U. 2010. ALILETOESCVR: Linguistica Baltica Delle Origini. Livorno: Books \& Company.

Dini, Pietro U. 2014. The Latin Theory and Vilnius Latinizers. In Prelude to Baltic Linguistics: Earliest Theories about Baltic Languages (16th Century). Leiden: Brill, pp. 45-82.

Ditchfield, Simon. 1995. Liturgy, Sanctity, and History in Tridentine Italy: Pietro Maria Campi and the Preservation of the Particular. New York: Cambridge University Press.

Ditchfield, Simon. 2007. Tridentine Worship and the Cult of Saints. In The Cambridge History of Christianity, vol. 6, Reform and Expansion, 1500-1600. Edited by R. Po-Chia Hsia. New York: Cambridge University Press, pp. 201-24.

Ditchfield, Simon. 2009. Thinking with Saints: Sanctity and Society in the Early Modern World. Critical Inquiry 35: 552-84. [CrossRef]

Donecker, Stefan. 2010. The Lion, the Witch and the Walrus: Images of the Sorcerous North in the 16th and 17th Centuries. TRANS Internet-Zeitschrift für Kulturwissenschaften 17. Available online: http://www.inst.at/trans/17Nr/4-5/4-5_donecker.htm (accessed on 4 October 2021).

Donecker, Stefan. 2016. Est vera India septemtrio: Re-imagining the Baltic in the age of discovery. In Re-forming Texts, Music, and Church Art in the Early Modern North. Edited by Tuomas Lehtonen and Linda Kaljundi. Amsterdam: Amsterdam University Press, pp. 393-419.

Donecker, Stefan. 2018. The Vagina nationum in the Sixteenth and Seventeenth Centuries: Envisioning the North as a Repository of Migrating Barbarians. In Visions of North in Premodern Europe. Edited by Dolly Jørgensen and Virginia Langum. Turnhout: Brepols, pp. 307-28.

Elsner, Jaś. 2000. From the culture of spolia to the cult of relics: The Arch of Constantine and the genesis of late antique forms. Papers of the British School at Rome 68: 149-84. [CrossRef]

Etkind, Alexander. 2011. Barrels of fur: Natural resources and the state in the long history of Russia. Journal of Eurasian Studies 2: 164-71. [CrossRef]

Flynn, Dennis, and Arturo Giráldez. 1995. Born with a 'Silver Spoon': The Origin of World Trade in 1571. Journal of World History 6: 201-21. 
Freddolini, Francesco. 2020. Francesco Paolsanti Indiano and His Early Seventeenth-Century Trade Between Florence and Goa. In Art, Mobility, and Exchange in Early Modern Tuscany and Eurasia. Edited by Francesco Freddolini and Marco Musillo. New York: Routledge, pp. 146-66.

Frick, David. 2013. Kith, Kin, and Neighbors: Communities and Confessions in Seventeenth-Century Wilno. Ithaca: Cornell University Press. Frost, Robert. 1993. After the Deluge: Poland-Lithuania and the Second Northern War, 1655-1660. Cambridge: Cambridge University Press. Frost, Robert. 2015. The Oxford History of Poland-Lithuania, vol. I: The Making of the Polish-Lithuanian Union, 1385-1569. New York: OUP. Galkus, Juozas. 2009. Lietuvos Vytis: Albumas. Vilnius: Vilniaus dailès akademijos leidykla.

Gennaioli, Riccardo, and Maria Sframeli, eds. 2014. Sacri Splendori: Il Tesoro Della 'Cappella Delle Reliquie' in Palazzo Pitti. Livorno: Sillabe.

Ghezzi, Renato. 2012. Livorno e l'Atlantico: I commerci olandesi nel Mediterraneo del Seicento. Bari: Cacucci.

Girkus, Romualdas, and Viktoras Lukoševičius. 2012. Europinė Sarmatija ankstyvojoje kartografijoje/Reflection of European Sarmatia in Early Cartography. Geodesy and Cartography 36: 123-29. [CrossRef]

Giusti, Annamaria. 1997. The Grand Ducal Workshops at the Time of Ferdinando I and Cosimo II. In Treasures of Florence: The Medici Collection 1400-1700. Edited by Cristina Acidini Luchinat. Munich: Prestel, pp. 115-43.

Giusti, Annamaria. 2003. Torricelli, Giuseppe Antonio. Grove Art Online. Available online: https://www.oxfordartonline.com/ groveart/view/10.1093/gao/9781884446054.001.0001/ oao-9781884446054-e-7000085746 (accessed on 3 November 2021).

Grabowska, Janina. 1971. The Diplomatic Career of Gdańsk Amber. Poland 8: 31-32.

Grusiecki, Tomasz. 2017. Foreign as Native: Baltic Amber in Florence. World Art 7: 3-36. [CrossRef]

Grusiecki, Tomasz. 2018. Uprooting Origins: Polish-Lithuanian Art and the Challenge of Pluralism. In Globalizing East European Art Histories: Past and Present. Edited by Beáta Hock and Anu Allas. New York: Routledge, pp. 25-38.

Grusiecki, Tomasz. forthcoming. Sarmatia Revisited: Maps and the Making of the Polish-Lithuanian Commonwealth. In Diversity and Difference in Poland-Lithuania and Its Successor States. Edited by Stanley Bill and Simon Lewis. Pittsburgh: University of Pittsburgh Press.

Guarini, Elena Fasano. 1984. COSIMO III de' Medici, granduca di Toscana. Dizionario Biografico degli Italiani 30. Available online: https: //www.treccani.it/enciclopedia/cosimo-iii-de-medici-granduca-di-toscana_(Dizionario-Biografico)/ (accessed on 4 October 2021).

Guérin, Sarah M. 2013. Meaningful Spectacles: Gothic Ivories Staging the Divine. Art Bulletin 95: 53-77. [CrossRef]

Guidetti, Giovanni Matteo. 2004. Novità e precisazioni sulla formazione artistica di Michele Arcangelo Palloni. In Artyści włoscy w Polsce XV-XVIII wiek. Edited by Joanna Pomorska. Warsaw: Wydawn "DiG", pp. 264-92.

Guidetti, Giovanni Matteo. 2008. Additional Information about the Sources of Michele Arcangelo Palloni's Artistic Language. Acta academiae artium Vilnensis 51: 75-89.

Guidetti, Giovanni Matteo. 2012. Il reliquairio di santa Maria Maddalena de’Pazzi a Vilnius e l'attività di Giovanni Comparini e Giuseppe Vanni per la corte di Toscana: Nuovi documenti. Bollettino della Accademia degli Euteleti della Città di San Miniato 79 : 197-215.

Guidetti, Giovanni Matteo. 2018. Firenze e Lituania. Un rapporto antico, un legame ritrovato. Essay for exhibition Firenze tra Rinascimento e Barocco. Dalle Collezioni d'Arte della Fondazione Cassa di Risparmio di Firenze e di Banca CR Firenze SpA. Vilnius. Available online: https:/ / www.fondazionecrfirenze.it/la-collezione-di-fondazione-cr-firenze-in-mostra-a-vilnius/ (accessed on 4 October 2021).

Guile, Carolyn C. 2018. Reflections on the Politics of Portraiture in Early Modern Poland. In Globalizing East European Art Histories: Past and Present. Edited by Beáta Hock and Anu Allas. New York: Routledge, pp. 83-97.

Gupta, Pamila. 2014. The Relic State: St Francis Xavier and the Politics of Ritual in Portuguese India. Manchester: Manchester University Press.

Guzmán, Miguel Taín. 2018. A Medici Pilgrimage: The Devotional Journey of Cosimo III to Santiago De Compostela (1669). Turnout: Brepols.

Hahn, Cynthia. 2013. Strange Beauty: Issues in the Making and Meaning of Reliquaries. University Park: Pennsylvania State University Press.

Hajdukiewicz, Leszek. 1982-1983. Pograbka (Pograbius) Andrzej. In Polski stownik biograficzny; Warsaw: Narodowy Instytut Audiowizualny. Available online: http:/ / www.ipsb.nina.gov.pl/a/biografia/andrzej-pograbka (accessed on 4 October 2021).

Harmatta, János. 1996. The Scythians. In History of Humanity. Vol. 3: From the Seventh Century B.C. to the Seventh Century A.D. Edited by Joachim Herrmann and Erik Zürcher. New York: Routledge, pp. 181-82.

Heinzelmann, Martin. 2002. Translation (von Reliquien). Lexikon des Mittelalters 8: 947-49.

Herz, Alexandra. 1988. Cardinal Cesare Baronio's Restoration of SS. Nereo ed Achilleo and S. Cesareo de'Appia. The Art Bulletin 70: 590-620. [CrossRef]

Hills, Helen. 2016. The Matter of Miracles: Neapolitan Baroque Architecture and Sanctity. Manchester: Manchester University Press.

Hills, Helen. 2020. Silver's Eye: Naples, Excess, and Spanish Colonialism. In Nature and the Arts in Early Modern Naples. Edited by Frank Fehrenbach and Joris van Gastel. Berlin: De Gruyter, pp. 81-104.

Hinrichs, Kerstin. 2007. Bernstein, das 'Preußische Gold' in Kunst- und Naturalienkammern und Museen des 16.-20. Jahrhunderts. Ph.D. thesis, Humboldt.-Universität, Berlin, Germany.

Hofmeester, Karin. 2016. Diamonds as global luxury commodity. In Luxury in Global Perspective: Objects and Practices, 1600-2000. Edited by Karin Hofmeester and Bernd-Stefan Grewe. Cambridge: Cambridge University Press, pp. 55-90. 
Houben, Hubert, and Kristjan Toomaspoeg, eds. 2008. L'Ordine Teutonico tra Mediterraneo e Baltico: Incontri e scontri tra religioni, popoli e culture. Begegnungen und Konfrontationen zwischen Religionen, Völker und Kulturen. Galatina: Mario Congedo Editore.

Jamski, Piotr. 2005a. The Building Stones of Zygmunt III Vasa in the Grand Duchyof Lithuania. In Actes du XIVe Colloque International de Glyptographie de Chambord 'du 19-23 juillet 2004. Braine-le-Château: Ed. de la Taille d'Aulme, pp. 503-21.

Jamski, Piotr. 2005b. Ołtarz relikwiarzowy w wileńskiej Kaplicy św. Kazimierza w pierwszej połowie XVII wieku. Barok. HistoriaLiteratura-Sztuka 12: 41-71.

Jamski, Piotr. 2008. Kaplica św. Kazimierza w Wilnie i jej twórcy. LDK Sakralinè Dailè: Atodangos ir Naujieji Kontekstai, Acta Academiae Artium Vilnensis 51: 91-112.

Jobst, Kerstin S. 2012. Transnational and Trans-Denominational Aspects of the Veneration of Saint Josaphat Kuntsevych. Journal of Ukrainian Studies 37: 1-17.

Jørgensen, Dolly. 2018. Beastly Belonging in the Premodern North. In Visions of North in Premodern Europe. Edited by Dolly Jørgensen and Virginia Langum. Turnhout: Brepols, pp. 183-205.

Jørgensen, Dolly, and Virginia Langum, eds. 2018. Visions of North in Premodern Europe. Turnhout: Brepols.

Jučas, Mečislovas. 1994. Théorie d'après laquelle la Lituanie et les nobles lituaniens sont originaires des Romains. In La via dell'ambra: Dal Baltico all'Alma Mater. Atti del Convegno italo-baltico, Bologna 18-20 settembre 1991. Edited by R. C. Lewanski. Bologna: Università degli Studi di Bologna, pp. 245-51.

Karpowicz, Mariusz. 2002. Artisti Ticinesi in Polonia Nella Prima metà del Seicento. Lugano: Edizioni Ticino Management S. A.

Karpowicz, Mariusz. 2003. Matteo Castello. L'architetto del Primo Barocco a Roma e in Polonia. Lugano: Edizioni Ticino Management.

Kazan, Georges, and Tom Higham. 2019. Researching relics: New interdisciplinary approaches to the study of historic and religious objects. In Life and Cult of Cnut the Holy: The First Royal Saint of Denmark. Edited by Steffen Hope. Odense: Syddansk Universitetsforlag, pp. 142-67.

Kiaupa, Zigmantas, Jurate Kiaupiene, and Albinas Kuncevicius. 2000. The History of Lithuania before 1795. Vilnius: Lithuanian Institute of History.

King, Rachel. 2009a. The Shining Example of "Prussian Gold": Amber and Cross-Cultural Connections between Italy and the Baltic in the Early Modern Period. In Materiał rzeźby: Między techniką a semantyka. Edited by Aleksandra Lipińska. Wrocław: Wydawn Uniwersytetu Wrocławskiego, pp. 456-70.

King, Rachel. 2009b. Whale's Sperm, Maiden's Tears and Lynx's Urine: Baltic Amber and the Fascination for It in Early Modern Italy. Ikonotheka 22: 168-79.

King, Rachel. 2013a. Finding the Divine Falernian: Amber in Early Modern Italy. VEA Online Journal 5. Available online: http://www. vam.ac.uk/content/journals/research-journal/issue-no.-5-2013/finding-the-divine-falernian-amber-in-early-modern-italy/ (accessed on 3 October 2021).

King, Rachel. 2013b. The Beads with Which We Pray Are Made from It: Devotional Ambers in Early Modern Italy. In Religion and the Senses in Early Modern Europe. Edited by Christine Göttler and Wietse de Boer. Brill: Leiden, pp. 153-75.

King, Rachel. 2014. Whose Amber? Changing Notions of Amber's Geographical Origin. Ostblick 2: 1-22.

Knoll, Paul. 1982. Jan Długosz, 1480-1980. The Polish Review 27: 3-28.

Kotljarchuk, Andrej. 2006. In the Shadows of Poland and Russia: The Grand Duchy of Lithuania and Sweden in the European Crisis of the mid-17th Century. Huddinge: Södertörns University.

Koutny-Jones, Aleksandra. 2015. Visual Cultures of Death in Central Europe: Contemplation and Commemoration in Early Modern Poland-Lithuania. Leiden: Brill.

Kriegseisen, Wojciech, Bartosz Wójcik, and Alex Shannon. 2016. Between State and Church: Confessional Relations from Reformation to Enlightenment: Poland, Lithuania, Germany, Netherlands. Frankfurt am Main: Peter Lang.

Kudachinova, Chechesh. 2019. The Muscovite Silver Crusade: Power, Space, and Imagination in Early Modern Eurasia. Ab Imperio 4: 49-72. [CrossRef]

Kulicka, Elżbieta. 1980. Legenda o rzymskim pochodzeniu Litwinów i jej stosunek do mitu sarmackiego. Przeglad historyczny 71: 1-21.

Langedijk, Karla. 1971. A New Cigoli: The State Portrait of Cosimo I De' Medici, and a Suggestion concerning the Cappella De' Principi. The Burlington Magazine 113: 575-79.

Lazure, Guy. 2007. Possessing the Sacred: Monarchy and Identity in Philip II's Relic Collection at the Escorial. Renaissance Quarterly 60: 58-93. [CrossRef]

Le Pouésard, Emma. 2019. By the skin of its teeth: Walrus ivory, the artisan, and other bodies. Postmedieval 10: 316-25. [CrossRef]

Lévi-Strauss, Claude. 1982. The Way of the Masks. Translated by Sylvia Modelski. Seattle: University of Washington Press.

Levy, Evonne. 1997. Reproduction in the 'Cultic Era of Art': Pierre Legros's Stanislas Kostka. Representations 58: 88-114. [CrossRef]

Lewanski, Riccardo Casimiro, ed. 1994. La via dell'Ambra. Dal Baltico All'Alma Mater. Atti Del Convegno Italico-Baltico. Bologna: Università degli Studi.

Mączyński, Ryszard. 2003. Nowożytne Konfesje Polskie. Artystyczne Fory Gloryfikacji Grobów Świętych i BłogosłAwionych w Dawnej Rzeczypospolitej. Torun: Wydawnictwo UMK.

Mączyński, Ryszard. 2005. Konfesje-Ziemskie groby niebiańskich orędowników. Spotkania z Zabytkami XXIX: 8-11.

Markey, Lia. 2016. Imagining the Americas in Medici Florence. University Park: Pennsylvania State University Press.

Martin, Janet. 1986. Treasure of the Land of Darkness: The Fur Trade and Its Significance for Medieval Russia. Cambridge: Cambridge University Press. 
Martines, Lauro. 2004. April Blood: Florence and the Plot against the Medici. London: Oxford University Press.

Maslauskaitè, Sigita. 2005. Neregètas šventasis Kazimieras. Naujasis Židinys-Aidai 6: 233-37.

Maslauskaitè, Sigita. 2006. Šv. Kazimiero relikvijos ir relikvijoriai. Acta academiae artium Vilnensis 41: 35-57.

Maslauskaitè-Mažylienè, Sigita. 2010. Šventojo Kazimiero atvaizdo istorija XVI-XVIII a. Vilnius: Lietuvos nacionalinis muziejus.

Maslauskaitè-Mažylienè, Sigita. 2013. Dzieje wizerunku św. Kazimierza od XVI do XVIII wieku. Między ikonografia a tekstem, z języka litewskiego przełożyła Katarzyna Korzeniewska. Vilnius: Publishing House of the Vilnius Art Academy.

Maslauskaitė-Mažylienė, Sigita, ed. 2018. Masterpieces of the history of the veneration of St. Casimir: Lithuania - Italy. Vilnius: Bažnytinio paveldo muziejus.

Mitrulevičiūtè, Daiva, ed. 2016. Lietuva-Italija: šimtmečiu ryšiai. Vilnius: Išleido Nacionalinis muziejus Lietuvos Didžiosios Kunigaikštystès valdovų rūmai.

Modesti, Adelina. 2020. Women's Patronage and Gendered Cultural Networks in Early Modern Europe: Vittoria della Rovere, Grand Duchess of Tuscany. New York: Routledge.

Mollisi, Giorgio, ed. 2013. Gli artisti del lago di Lugano e del Mendrisiotto nel Granducato di Lituania (dal XVI al XVIII sec.). Lugano: Edizioni Ticino Management.

Monroe, William H. 1978. An Early French Ivory of the Virgin and Child. Museum Studies 9: 7-29.

Moore, Jason. 2010a. 'Amsterdam is Standing on Norway,' Part I: The Alchemy of Capital, Empire and Nature in the Diaspora of Silver, 1545-1648. Journal of Agrarian Change 10: 33-68. [CrossRef]

Moore, Jason. 2010b. 'Amsterdam is Standing on Norway' Part II: The Global North Atlantic in the Ecological Revolution of the Long Seventeenth Century. Journal of Agrarian Change 10: 188-227. [CrossRef]

Moore, Jason. 2010c. "This lofty mountain of silver could conquer the whole world": Potosí and the Political Ecology of Underdevelopment, 1545-1800. Journal of Philosophical Economics 4: 58-103.

Morawski, Paolo. 1989. 'Le 'Indie d'Europa'. Tre schede per una ricerca in corso. Europa Orientalis 8: 301-12.

Mottana, Annibale. 2006. Italian gemology during the Renaissance: A step toward modern mineralogy. In The Origins of Geology in Italy. Edited by Gian Battista Vai and W. Glen E. Caldwell. Boulder: Geological Society of America, pp. 1-21.

Murray, Alan, ed. 2001. Crusade and Conversion on the Baltic Frontier, 1150-1500. Burlington: Ashgate.

Murray, Alan, ed. 2009. The Clash of Cultures on the Medieval Baltic Frontier. Burlington: Ashgate.

Murray, Alan. 2010. The Saracens of the Baltic: Pagan and Christian Lithuanians in the Perception of English and French Crusaders to Late Medieval Prussia. Journal of Baltic Studies 41: 413-29. [CrossRef]

Musillo, Marco. 2020. The Russian Fata Morgana of Cosimo III: The Fluctuating Portraits of Kangxi between Florence and Beijing. In Art, Mobility, and Exchange in Early Modern Tuscany and Eurasia. Edited by Francesco Freddolini and Marco Musillo. New York: Routledge, pp. 167-86.

Nef, John U. 1941. Silver Production in Central Europe, 1450-1618. Journal of Political Economy 49: 575-91. [CrossRef]

Netzer, Susanne. 1993. Bernsteingeschenke in der preussischen Diplomatie des 17. Jahrhunderts. Jahrbuch Der Berliner Museen 35: 227-46. [CrossRef]

Noonan, Thomas, and Roman Kovalev. 2004. The Furry 40's. Packaging Pelts in Medieval Northern Europe. In States, Societies, Cultures, East and West. Essays in Honor of Jaroslaw Pelenski. Edited by Janusz Duzinkiewicz. New York: Ross, pp. 653-82.

Nowakowska, Natalia. 2014. High clergy and printers: Anti-Reformation polemic in the kingdom of Poland, 1520-36. Historical Research 87: 43-64. [CrossRef]

Noyes, Ruth Sargent. 2018. Peter Paul Rubens and the Counter-Reformation crisis of the Beati moderni. New York: Routledge.

Noyes, Ruth Sargent. forthcoming. 'The Polar Winds have driven me to the conquest of the Treasure in the form of the much-desired relic.' (Re)moving relics and performing gift exchange between early modern Tuscany and Lithuania. In Gifts and Materiality: Gifts as Objects in Medieval and Early Modern Europe. Edited by Gustavs Strenga and Lars Kjar. London: Bloomsbury.

Orzeł, Joanna. 2010. Sarmatism as Europe's Founding Myth. Polish Political Science Yearbook XXXIX: 149-57.

Orzeł, Joanna. 2019. From imagination to political reality? The Grand Duchy of Lithuania as a successor of Rome in the early modern historiography (15th-18th centuries). Open Political Science 1: 170-81. [CrossRef]

Ostrow, Steven. 2009. The 'Confessio' in Post-Tridentine Rome. In Arte e committenza nel Lazio nell'età di Cesare Baronio. Edited by Patrizia Tosini. Rome: Gangemi, pp. 19-32.

Panella, Antonio. 1917. Candidati italiani al trono polacco. I Medici. Rassegna Nazionale 16: 269-79.

Papée, Fryderyk. 1939-1946. Długosz h. Wieniawa (Ioannes Dlugossius, Longinus) Jan. In Polski stownik biograficzny; Warsaw: Narodowy Instytut Audiowizualny. Available online: http:/ /www.ipsb.nina.gov.pl/a/biografia/jan-dlugosz-h-wieniawa-1415 -1480-kanonik-krakowski-historyk (accessed on 4 October 2021).

Piacenti, Kirsten Aschengreen. 1966. Due altari in ambra al Museo degli Argenti. Bolletino d'arte 51: $163-66$.

Platania, Gaetanio. 1992. Venimus, Vidimus Et Deus Vicit: Dai Sobieski Ai Wettin, La Diplomazia Pontificia Nella Polonia Di Fine Seicento. Cosenza: Periferia.

Platania, Gaetanio. 2000. "Rzeczpospolita," Europa E Santa Sede Tra Intese Ed Ostilità: Saggi Sulla Polonia Del Seicento. Viterbo: Sette Città.

Platania, Gaetanio. 2011. Polonia e Curia Romana: Corrispondenza tra Giovanni III Sobieski, re di Polonia con Carlo Barberini protettore del Regno. Viterbo: Sette Città.

Poole-Jones, Katherine. 2020. The Medici, Maritime Empire, and the Enduring Legacy of the Cavalieri Di Santo Stefano. In Florence in the Early Modern World: New Persepctives. Edited by Nicholas Scott Baker and Brian Maxson. New York: Routledge, pp. 156-86. 
Quirini-Popławska, Danuta. 1982. La corte di Toscana e la terza elezione in Polonia. Zeszyty Naukowe Uniwersytetu Jagiellońskiego. Prace Historyczne 71: 49-66.

Quirini-Popławska, Danuta. 1998. Dwór medycejski i Habsburgowie a trecia elecja w Polsce. Odrodzenie i Reformacja w Polsce 42: 121-32.

Rabikauskas, Paulius, ed. 1989. La Cristianizzazione Della Lituania. Atti del Colloquio Internazionale di Storia Ecclesiastica in Occasione del 6 Centenario Della Lituania Cristiana (1387-1987). Roma, 24-26 Giugno 1987. Città del Vaticano: Libreria editrice vaticana.

Rachuba, Andrzej. 1979. Mikołaj Stefan Pac. In Polski Słownik Biograficzny. Wroclaw: Zakład Narodowy im. Ossolińskich, vol. 14, pp. $738-41$.

Rijkelijkhuizen, Marloes. 2009. Whales, Walruses, and Elephants: Artisans in Ivory, Baleen, and Other Skeletal Materials in Seventeenthand Eighteenth-Century Amsterdam. International Journal of Historical Archaeology 13: 409-29. [CrossRef]

Ronchi De Michelis, Laura. 2003. GUAGNINI, Alessandro. Dizionario Biografico degli Italiani 60. Available online: https://www. treccani.it/enciclopedia/alessandro-guagnini_(Dizionario-Biografico) (accessed on 4 October 2021).

Rowell, Stephen C. 2002. Lietuva-krikščonybės pylimas?: Vienos XV amžiaus ideologijos pasisavinimas. In Europos idejja Lietuvoje: Istorija ir dabartis. Edited by Darius Staliūnas. Vilnius: Lietuvos istorijos institutas, pp. 17-32.

Rowell, Stephen C. 2014. Lithuania Ascending: A Pagan Empire within East-Central Europe, 1295-1345. Cambridge: CUP.

Rubinson, Karen. 1975. Herodotus and the Scythians. Expedition Magazine 17: 16-20. Available online: http://www.penn.museum/ sites/expedition/?p=2981 (accessed on 4 October 2021).

Rush, Alfred C. 1962. Spiritual Martyrdom in St. Gregory the Great. Theological Studies 23: 569-89. [CrossRef]

Sand, Alexa. 2014. Materia Meditandi: Haptic Perception and Some Parisian Ivories of the Virgin and Child, ca. 1300. Different Visions: A Journal of New Perspectives on Medieval Art 4: 1-28.

Sanger, Alice E. 2014. Art, Gender and Religious Devotion in Grand Ducal Tuscany. Burlington: Ashgate.

Schmidt, Eike D. 2008. Cardinal Ferdinando, Maria Maddalena of Austria, and the Early History of Ivory Sculptures at the Medici Court. Studies in the History of Art 70: 158-83.

Schmidt, Eike D. 2012. Das Elfenbein der Medici: Bildhauerarbeiten für den florentiner Hof. München: Hirmer.

Schoonhoven, Erik. 2010. A Literary Invention: The Etruscan Myth in Early Renaissance Florence. Renaissance Studies $24: 459-71$. [CrossRef]

Sherrill, Tawny. 2006. Fleas, Furs, and Fashions: Zibellini as Luxury Accessories of the Renaissance. In Medieval Clothing and Textiles. Edited by Robin Netherton and Gale R. Owen-Crocker. Woodbridge: Boydell Press, vol. 2, pp. 121-50.

Silva, Joseph M. 2020. To the Victor Go the Spoils: Christian Triumphalism, Cosimo I de' Medici and the Order of Santo Stefano in Pisa. In Art, Mobility, and Exchange in Early Modern Tuscany and Eurasia. Edited by Francesco Freddolini and Marco Musillo. New York: Routledge, pp. 33-47.

Spinelli, Riccardo. 2019. Le Committenze Sacre Di Cosimo III De' Medici: Episodi Poco Noti o Sconosciuti (1677-1723). Florence: Edifir Edizioni Firenze.

Srodecki, Paul. 2015. Antemurale Christianitatis: Zur Genese der Bollwerksrhetorik im östlichen Mitteleuropa an der Schwelle vom Mittelalter zur Frühen Neuzeit. Husum: Matthiesen Verlag.

Stöve, Eckehart. 1996. FERRERI, Zaccaria. Dizionario Biografico degli Italiani 46. Available online: https://www.treccani.it/enciclopedia/ zaccaria-ferreri_(Dizionario-Biografico)/ (accessed on 4 October 2021).

Ström, Helena Wangefelt, and Federico Barbierato. 2018. Omne malum ab Aquilone: Images of the Evil North in Early Modern Italy and their Impact on Cross-Religious Encounters. In Visions of North in Premodern Europe. Edited by Dolly Jørgensen and Virginia Langum. Turnhout: Brepols, pp. 265-86.

Suchocki, Jerzy. 1987. Geneza litewskiej legendy etnogenetycznej. Aspekty polityczne i narodowe. Zapiski Historyczne 52: $27-67$.

Tamm, Marek. 2009. A New World into Old Words: The Eastern Baltic Region and the Cultural Geography of Medieval Europe. In The Clash of Cultures on the Medieval Baltic Frontier. Edited by Alan V. Murray. Aldershot: Ashgate, pp. 11-35.

Tamm, Marek, Linda Kaljundi, and Carsten Selch Jensen, eds. 2011. Crusading and Chronicle Writing on the Medieval Baltic Frontier: A Companion to the Chronicle of Henry of Livonia. Farnham: Ashgate.

Tazzara, Corey. 2020a. Port of Trade or Commodity Market? Livorno and Cross-Cultural Trade in the Early Modern Mediterranean. Business History Review 94: 201-28. [CrossRef]

Tazzara, Corey. 2020b. Disembedding the Market. Commerce, Competition, and the Free Port of 1676. In Art, Mobility, and Exchange in Early Modern Tuscany and Eurasia. Edited by Francesco Freddolini and Marco Musillo. New York: Routledge, pp. 69-84.

Teles e Cunha, João. 2001. Hunting Riches: Goa's Gem Trade in the Early Modern Age. In The Portuguese, Indian Ocean and European Bridgeheads 1500-1800: Festschrift in Honour of Prof. K. S. Mathew. Edited by Pius Malekandathil and Jamal Mohammed. Tellicherry: Institute for Research in Social Sciences and Humanities of MESHAR, pp. 269-304.

Trivellato, Francesca. 2000. From Livorno to Goa and Back: Merchant Networks and the Coral-Diamond Trade in the Early-Eighteenth Century. Portuguese Studies 16: 193-217.

Tutino, Stefania. 2013. 'For the Sake of the Truth of History and of the Catholic Doctrines': History, Documents, and Dogma in Cesare Baronio's Annales Ecclesiastici. Journal of Early Modern History 17: 125-59. [CrossRef]

Tygielski, Wojciech. 2015. Italians in Early Modern Poland: The Lost Opportunity for Modernization? Bern: Peter Lang.

Urban, William. 2003. The Teutonic Knights: A Military History. St. Paul: MBI Publishing.

Ward-Perkins, John Bryan. 1952. The Shrine of St. Peter and its Twelve Spiral Columns. Journal of Roman Studies XLII: 21-33. 
Wieland, Franz. 1906. Mensa und Confessio: Studien über den Altar der Altchristlichen Liturgie. Munich: J.J. Lentner, 2 vols.

Wolff, Larry. 1994. Inventing Eastern Europe. The Map of Civilization on the Mind of the Enlightenment. Stanford: Stanford University Press.

Žygas, K. Paul. 1996. Dogma, Art and Politics: Roman Aspects of St. Casimir's Chapel in Vilnius. Journal of Baltic Studies 27: 175-212. [CrossRef]

Žygas, K. Paul. 2000. The Spirit of Austerity and the Materials of Opulence: Architectural Sources of St. Casimir's Chapel in Vilnius. Journal of Baltic Studies 31: 5-43. [CrossRef] 